\title{
O FIM DO TRATAMENTO DIFERENCIADO E A ADOÇÃO DA REGRA DE RECIPROCIDADE PARA PAÍSES EM DESENVOLVIMENTO NA RODADA URUGUAI DA OMC
}

\author{
Feliciano de Sá Guimarães
}

\begin{abstract}
RESUMO
O artigo pretende compreender como as negociações da Rodada Uruguai (1986-1994) e as pressões dos países desenvolvidos tiveram efeito sobre a reorientação dos posicionamentos dos países em desenvolvimento no âmbito multilateral do comércio. Nesse sentido, revisamos as estratégias de ambos os grupos de países (desenvolvidos e em desenvolvimento) na condução e construção das regras do regime e como esse processo refletia um ambiente de coerção e pactuação assimétrica que levou os países em desenvolvimento a adotar a liberalização comercial como única estratégia comercial possivel ao final das negociações.
\end{abstract}

PALAVRAS-CHAVE: Organização Mundial do Comércio; Rodada Uruguai (1986-1994); países desenvolvidos; países em desenvolvimento; regra de reciprocidade; tratamento diferenciado.

\section{INTRODUÇÃO}

Lançada em setembro de 1986, em Punta del Este, a Rodada Uruguai foi descrita como "o mais complexo e ambicioso programa de negociações jamais realizado pelo GATT [General Agreement on Tariffs and Trade]" (GATT, oct.1986 at.1). Depois de nove anos de intensas tratativas tal frase mostrou-se profética.

Essa ambiciosa reestruturação do comércio aconteceu durante uma década conturbada tanto do ponto de vista político como econômico. Os nove anos da Rodada foram marcados por transformações profundas na ordem mundial. Em meio a idas e vindas dos diplomatas a Genebra, cidade sede do GATT, o Muro de Berlim caiu e os 40 anos de história da Guerra Fria foram subitamente alterados pelos eventos emanados de Moscou e Washington. O lançamento da Rodada aconteceu em certo mundo, seu fim já se encontrava em outro.

Ao cabo das negociações, na Reunião Ministerial de Marraqueche em abril de 1994, os países acordaram em criar uma instituição que representasse da melhor forma possível as relações comerciais que se dariam em uma nova ordem internacional - a Organização Mundial do Comércio - ainda que nenhum político, filósofo ou diplomata soubesse como poderia ser essa nova configuração mundial.

Nesse contexto, o Brasil talvez tenha sido, ao lado da Índia, o mais importante e decisivo país em desenvolvimento ${ }^{1}$. E se o mundo migrou do bipolarismo para o multipolarismo ou unipolarismo entre o início e o fim da Rodada, o Brasil e outros países em desenvolvimento (Argentina, Índia, Paquistão, Egito, Coréia do Sul etc.) também alteraram o perfil de suas organizações socioeconômicas, ou seja, deixaram de lado a prática de substituir importações e adotaram a liberalização econômica. Em linguagem comercial, mais precisamente, essas mudanças significaram o abandono do tratamento diferenciado e a aceitação da prática de reciprocidade, termos que discutire-

\footnotetext{
1 O termo "país em desenvolvimento", embora polêmico, é bastante utilizado nesse artigo. Por "país em desenvolvimento" caracterizamos aqueles países classificados pela própria instituição (GATT) como intermediários em suas trocas comerciais. Além disso, tais países agiam de forma conjunta nas negociações e respondiam pelas alcunhas de "países em desenvolvimento", "países do Terceiro Mundo" ou "Não-alinhados" em alusão aos seus posicionamentos dentro do contexto da Guerra Fria. Nas atuais negociações comerciais (Rodada Doha) esse termo perdeu parte de sua capacidade explicativa, tanto por conta das mudanças sistêmicas quanto por conta dos próprios posicionamentos de diversos países que não mais se intitulam "em desenvolvimento".
} 
mos mais tarde. As políticas comerciais ${ }^{2}$ dos países em desenvolvimento foram marcadas, portanto, por mudanças importantes tanto na sua concepção como na sua orientação e implementação e, em nossa opinião, a Rodada Uruguai teve influência fundamental nesse sentido.

Sendo assim, o objetivo geral do presente estudo é compreender como o contexto de negociação da Rodada Uruguai (1986-1994) influenciou a atuação dos países em desenvolvimento no plano multilateral rumo à liberalização comercial. Procuramos analisar como a lógica de negociação de uma Rodada distinta das anteriores acabou por influenciar as estratégias comerciais desses países, impondo às autoridades locais a necessidade de reestruturação nas políticas comerciais vigentes, no sentido de acatarem as novas regras comerciais que surgiam ao longo da Rodada, sobretudo aquelas que representavam liberalização comercial (temas tradicionais) e harmonização de políticas públicas (novos temas) ${ }^{3}$.

Além disso, a abordagem que damos à Rodada procura salientar dois tipos de estratégias adotadas pelos países desenvolvidos, notadamente os EUA, que acabaram por ter papel relevante nas mudanças de posicionamento dos países em desenvolvimento ${ }^{4}$. Primeiro, o intuito de incluir no arcabouço jurídico da instituição os chamados novos temas (propriedade intelectual, serviços e

2 Nosso texto enfatiza os posicionamentos dos países em desenvolvimento no decorrer da Rodada. Sendo assim, as políticas comerciais são sempre vistas em relação a esses posicionamentos. As questões de ordem doméstica ou os aspectos mais gerais da política comercial como instrumento de regulação econômica de cada país são eventualmente lidas à luz dos posicionamentos. Não temos esses aspectos mais gerais de política comercial e/ou política externa como chave explicativa do texto. Nossa arena resume-se às negociações multilaterais e em que medida essas negociações influenciavam os posicionamentos dos países.

3 Os temas tradicionais são tidos como aqueles já tratados nas rodadas anteriores: tarifas, barreiras não tarifárias, cotas, subsídios, salvaguardas, medidas anti-dumping etc.; todos envolvidos em setores econômicos conhecidos da liberalização: agricultura e bens industriais. Já os novos temas representam setores econômicos até então não negociados, a saber, propriedade intelectual, serviços e investimentos relacionados ao comércio.

4 Utilizamos constantemente o conceito de regime internacional nesse artigo. Não pretendemos, contudo, analisar os aspectos teóricos mais gerais da escola criada após o surgimento do conceito em meados dos anos 1970 e início dos 1980 (KRASNER, 1983, p. 2). investimentos). E, segundo, a pressão no sentido de coibir os "caronas do comércio", normalmente tidos como países que aderiam parcialmente às obrigações do regime, graças a instrumentos de exceção às regras, sobretudo o tratamento diferenciado. Não custa lembrar que o Brasil era visto como um importante exemplo de "carona".

De modo geral, procuramos sustentar a hipótese segundo a qual o leque de possibilidades estratégicas dos países em desenvolvimento tornouse bastante limitado ao longo da evolução da Rodada, tanto por conta das pressões exercidas pelas grandes potências, que desejavam alterar toda a estrutura institucional do comércio (temas tradicionais e novos temas), como por razão da estrutura jurídica de negociação da instituição naquele momento. Ou seja, um processo de tomada de decisões tendencioso à manutenção dos países ricos na condução e constituição das regras e normas do regime. Em outras palavras, entendemos que a lógica de negociação da instituição, aliada às pressões exógenas promovidas pelos países desenvolvidos, pelas agências financeiras internacionais (Fundo Monetário Internacional (FMI) e Banco Mundial) e por alguns organismos intergovernamentais (G-7 e Organização para a Cooperação e do Desenvolvimento Econômico (OCDE)), acabaram por limitar as atuações dos países em desenvolvimento, forçando-os a alterarem suas estratégias e posicionamentos. A própria idéia de o Brasil, a Índia, a Argentina etc. agirem por meio de coalizões como forma de barrar essas pressões reflete o ambiente de difícil inserção para os países pobres.

Dividimos esse artigo em quatro partes, além desta introdução. A primeira (seção II) procura dar conta da participação dos países em desenvolvimento nas últimas rodadas do GATT, em especial as rodadas Dillon (1960-1961), Kennedy (1963-1967) e Tóquio (1974-1979). Essa parte salienta duas abordagens. Por um lado, enfatizamos as demandas desses países por regras que assegurassem o caráter peculiar de suas economias nas negociações, ou seja, um instrumento jurídico de tratamento diferenciado; e, por outro, procuramos demonstrar como os países desenvolvidos adotavam a prática de reciprocidade a fim de constituírem as regras e, conseqüentemente, liderarem o regime do comércio. A segunda parte (seção III) centraliza a explicação no processo de harmonização de políticas públicas (novos temas) que as rodadas Tóquio e Uruguai promoveram e, 
conseqüentemente, de que forma essa nova construção de regras influenciou a participação dos países em desenvolvimento. A terceira parte (seção IV) é destinada à compreensão da lógica de negociação da Rodada Uruguai e como esse processo limitou a atuação dos países em desenvolvimento, levando-os a adotarem a liberalização comercial como única estratégia possível. Por fim, na quarta parte (seção $\mathrm{V}$ ), procuramos desenhar um quadro geral dos posicionamentos dos países ao longo da Rodada, enfatizando os momentos nos quais os países em desenvolvimento adotaram os princípios negociadores das potências comerciais (ampliação dos novos temas e reciprocidade). Cabe antes uma breve introdução sobre o GATT.

Para Goldstein (1998, p. 22), a explicação do sucesso do GATT na redução das tarifas comerciais dos últimos 40 anos reside em uma regra central do regime, a saber, a reciprocidade entre as partes. Isto é, a fim de alcançarem um resultado mais substancial e equilibrado para todos, as partes procuram fazer concessões e demandas cruzadas $^{5}$. Cada país oferece uma lista daquilo que pretende ceder e lograr sobre cada tema em pauta $^{6}$. Com todas as propostas na mesa, ocorre uma tentativa multilateral no intuito de encontrar um equilíbrio entre concessões e ganhos para todos aqueles envolvidos na negociação. Como afirma Dam (1970, p. 17), realizada a concessão em determinado item, a tarifa alcançada tem caráter obrigatório contra qualquer outro aumento acima do que foi acordado. Retoricamente, a prática negociadora do sistema é a busca por uma pactuação equilibrada, e por isso cooperada entre as partes ${ }^{7}$.

\footnotetext{
5 O artigo XXVIII bis do GATT-1947 reza que as negociações devem ser "[...] on a reciprocal and mutually advantageous basis" e que "[...] negotiations shall be conducted on a basis which affords adequate opportunity to take into account the needs on individual contracting parties and individual industries" [respectivamente: "[...] em uma base recíproca e mutuamente vantajosa" e "[...] as negociações deverão ser conduzidas em uma base que proveja a oportunidade adequada para levar em consideração as necessidades individuais das partes contratantes e das indústrias individuais" - nota do editor].

6 O método de mensuração da reciprocidade é o trade coverage, que se refere ao volume anual de importações dentro de uma tarifa previamente classificada à qual a concessão em questão é aplicada.
}

${ }^{7}$ A literatura especializada em negociações comerciais não alcançou consenso sobre o termo "reciprocidade". Preferi-
Com a inclusão da Cláusula da Nação-maisFavorecida, essas concessões realizadas entre as partes são automaticamente estendidas às demais partes do regime (GATT, 1947, parte 1, art. $1^{\circ}, \S$ $\left.1^{\circ}\right)$. Desse modo, um corte mais substancial ocorrido em determinada barganha bilateral - EUA e Reino Unido, por exemplo - torna-se o ponto inicial a partir do qual barganhas subseqüentes ocorrem entre os demais países. Aqueles que apóiam esse processo o chamam de ação bilateral com implicações multilaterais (GOLDSTEIN, 1998, p. 27).

Sendo assim, o multilateralismo serve como importante estratégia institucional na medida em que faz o sistema caminhar por meio de trocas cruzadas e constantes. Em um sistema bilateral ou preferencial, conforme aqueles existentes nos anos 1930, não há essa mesma ênfase em negociações perenes. Enquanto o multilateralismo é caracterizado pelo dinamismo e tendência ao igualitarismo dos resultados ${ }^{8}$, os sistemas preferenciais são definidos pelos privilégios e estabilidade das relações.

As negociações tarifárias e não tarifárias do regime promoveram um processo contínuo de diminuição dos entraves ao comércio internacional. A diminuição desses procedimentos, contudo, não foi equânime nem entre os países membros nem entre os setores econômicos passíveis de liberalização. Pelo contrário, os países em desenvolvimento sofreram mais com escaladas tarifárias e não tarifárias, que acabaram por prejudicar as exportações de setores estratégicos (têxteis e agricultura) ${ }^{9}$. Como veremos ao longo do texto, esse processo ocorreu por conta de três

mos para essa pesquisa a definição acima colocada. Sobre discussões mais precisas do conceito, cf. Keohane (1986, p. 1-27).

8 A idéia de existência de certa igualdade dos resultados enseja o conceito cooperação. É importante frisar que a cooperação é resultado de uma coordenação política ("policy coordination") e em momento algum pressupõe ausência de conflito. Na realidade, significa esforços conjuntos para superar os conflitos reais ou potenciais, sendo, portanto, uma reação ao conflito. A cooperação significa ajustes de interesses e não meramente interesses em comum. Esse ajuste passa sempre pela barganha, ou seja, por ações diretas de um país no sentido de moldar as políticas do outro (KEOHANE, 1984, p. 52-54).

9 Em áreas do comércio em que foi permitido prevalecer os princípios do GATT, primariamente no comércio de ma- 
fatores básicos. Cabe ressaltá-los rapidamente aqui: primeiro, graças à regra de reciprocidade e sua característica mercantilista intrínseca que favorecia os países ricos; segundo, em razão da existência do tratamento diferenciado para os países em desenvolvimento que propiciava uma diminuição de suas trocas comerciais. E, por fim, em virtude de um ambiente institucional de negociação que ajudava as demandas dos países mais ricos em detrimento das exigências dos países em desenvolvimento.

Para que possamos entender cada um desses aspectos é salutar que se revise a participação dos países em desenvolvimento nas rodadas anteriores, em especial nas rodadas Dillon, Kennedy e Tóquio. Soma-se a isso a necessidade de discutir quais foram as demandas mais contundentes desses países no que diz respeito ao corpo das regras do regime. Com isso chegamos à seção II do artigo.

\section{APARTICIPAÇÃO DOS PAÍSES EM DESEN- VOLVIMENTO NO GATT: DA RODADA DILLON À RODADA TÓQUIO}

Houve uma mudança significativa no posicionamento dos países em desenvolvimento no regime do GATT a partir do início dos anos 1960. Mais especificamente são as rodadas Dillon e Kennedy que marcam o início de uma participação mais importante e contundente dos países em desenvolvimento no regime. Não que esses países estivessem fora das negociações nas décadas anteriores - o Brasil e a Índia são membros desde 1947 - mas foi a partir desse período que o posicionamento dos países do então chamado

nufaturas, o sistema de liberalização foi bastante exitoso. $\mathrm{O}$ volume do comércio mundial multiplicou nove vezes entre 1946 e 1985 . Nos anos 1950 e 1960 o volume de comércio cresceu duas vezes mais que a renda e o PIB. No início dos anos 1970, depois dos cortes tarifários realizados na Rodada Kennedy, os economistas previram que a tarifa média dos produtos manufaturados ficaria um pouco acima dos $9 \%$ no mundo desenvolvido. Com as reduções negociadas na Rodada Tóquio as tarifas médias já eram de 4,9\% nos EUA, 6,0\% na Europa e 5,4\% no Japão. Já ao final da Rodada Uruguai a média tarifária dos países membros havia sido reduzida de $6,3 \%$ para $3,9 \%$. Contudo, boa parte desses cortes ocorreu somente entre as potências industriais e os setores mais dinâmicos de suas economias. O volume de comércio de bens agrícolas e têxteis, por exemplo, caiu durante o mesmo período e barreiras comerciais generalizadas foram argüidas contras as exportações dos países em desenvolvimento (OXLEY, 1990, p. 9).
Terceiro Mundo começou a tomar uma forma mais significativa para o futuro do comércio.

De acordo com Velasco e Cruz isso ocorreu por conta de quatro razões distintas, porém interligadas. Primeiro a mudança no quadro geopolítico mundial. Os anos 1960 foram sintomáticos na constituição de um discurso articulado entre os países em desenvolvimento. Integrada por um grupo de países insatisfeitos com o bipolarismo, a periferia começou a questionar o universalismo retórico das organizações internacionais sob influência direta dos EUA. Estas nações buscavam uma visão alternativa do sistema, ou seja, uma visão que encerrasse melhor seus anseios nacionalistas e desenvolvimentistas crescentes. O Movimento dos Não-alinhados nasceu dessas demandas nas Conferências de Bandung (1955), Belgrado (1961) e Cairo (1962) (VELASCO E CRUZ, 2005, p. 48). Na esteira dos acontecimentos foi criada em 1964 a Conferência da Organização das Nações Unidas para o Comércio e o Desenvolvimento (United Nations Conference on Trade and Development (UNCTAD)), organismo multilateral que serviria como caixa de ressonância e de estudos das necessidades de desenvolvimento econômico e social dos países da periferia.

O segundo aspecto diz respeito ao sentimento comum de exclusão das trocas comerciais crescente por parte destes países ${ }^{10}$. O avanço econômico do período posterior à II Guerra Mundial não atingia as exportações dos países em desenvolvimento. No início dos anos 1950 a taxa média anual de crescimento das exportações desses países era de 8,4\%; dez anos depois a taxa havia caído para $5 \%$ (idem, p. 49). Os números indicavam uma diminuição da participação das exportações dos países em desenvolvimento nas trocas comerciais globais, ao passo que o comércio en-

\footnotetext{
10 É importante lembrar que o documento GATT-1947 não incluiu os parágrafos relacionados às necessidades de desenvolvimento econômico oriundos da Carta de Havana (OIC): "Employment and Economic Activit", "Economic Development and Reconstruction", "Restrictive Business Practices" e "International Governmental Commodity Agreements" [respectivamente: "Emprego e atividade econômica", "Desenvolvimento econômico e reconstrução", "Práticas comerciais restritivas" e "Tratados governamentais internacionais sobre produtos primários" - N. E.]. Apenas o parágrafo "Commercial Policy" da Carta de Havana seguiu com o GATT-1947 e ainda assim com emendas (DAM, 1970, p. 11).
} 
tre os países mais industrializados aumentava de maneira mais substancial.

Em terceiro lugar, diversos países do Terceiro Mundo tornaram-se membros efetivos do regime ao longo dos anos 1960 e 1970 (idem, p. 45). No início da década de 1960 eram 37 membros e nos anos do lançamento da Rodada Uruguai em 1986 já eram 99. Esse crescimento deu-se em grande medida pela inclusão sistemática de países recémindependentes e por países que aos poucos foram compreendendo a importância crescente de um regime como o GATT para suas economias (México $^{11}$, Coréia do Sul etc.).

Por fim, o quarto fator, e para nós o mais importante, foi a inclusão de regras de exceção à agenda negociadora do regime que passou a incorporar a temática do desenvolvimento econômico, com a inclusão da Parte IV ao documento GATT-1947 em $1965^{12}{ }^{13}$. Esse aspecto demonstrava uma visão diferenciada acerca do sentido do comércio para os países em desenvolvimento.

11 O caso mexicano é interessante. O país somente se tornou membro do regime em 1986. E quando entrou já cerrou fileiras ao lado da agenda dos EUA para a Rodada. As razões para essa abordagem podem ser diversas, mas uma nos chama a atenção. Antes de aderir ao GATT em 1986 o México assinou tratados bilaterais com os EUA em subsídios e anti-dumping, fazendo com que a liberalização comercial se tornasse inescapável (RUBIO, RODRIGUES \& BLUM, 1989, p. 173).

12 A partir da inclusão da Parte IV no GATT-1947 em 1965 os países em desenvolvimento começaram a gozar de certos direitos concedidos pelos mais ricos. Esses direitos estavam assegurados pelo Tratamento Diferenciado (S\&D). Os países em desenvolvimento eram beneficiados sem contrapartida pela expansão dos benefícios dos acordos firmados entre os países desenvolvidos. A Parte IV é vista pela literatura como uma resposta a crítica dos países em desenvolvimento ao regime do comércio após os fracos resultados da Rodada Kennedy.

13 Em 1958 foram publicados os esforços intelectuais do painel intitulado Trends in Intenational Trade (Tendências no comércio internacional), cujo objetivo era analisar a situação dos países em desenvolvimento nas trocas comerciais. Esse relatório ficou conhecido como The Habeler Report, em homenagem a um dos quatro economistas da equipe (Habeler, Meade, Tinbergen e Roberto Campos). A substância do relatório apontava para o fato de que o destino comercial dos países em desenvolvimento era ditado pelas políticas comerciais dos países ricos. Houve rápida reação do regime a essa constatação com a criação do 1963 Action Programme e da Parte IV em 1965 (DAM, 1970, p. 236-237).
De acordo com Winham, os países em desenvolvimento preferiam escapar do subdesenvolvimento por meio de concessões ao invés de criarem um regime de comércio essencialmente liberal. Na realidade, tais nações eram especialmente motivadas por teorias econômicas mais protecionistas, a fim de promover a substituição de importações e a expansão das exportações. Havia claras reticências às concessões comerciais e uma defesa da promoção das exportações. Essa abordagem mais mercantilista, segundo o autor, era a antítese do GATT e das teorias contemporâneas ou clássicas de comercio livre (WINHAM, 1986, p. 142). Mas por que os países em desenvolvimento pensavam diferente?

Segundo Hamilton e Whalley, vários fatores contavam para esse tipo de abordagem. Podemos citar os seguintes: a) uma forte crença no fato de que as dificuldades da balança de pagamentos eram endêmicas, o que conseqüentemente dificultava ou impossibilitava a liberalização; b) uma forte crença na política de substituição de importações como estratégia desejável para o crescimento econômico, gerando assim a necessidade máxima de proteção comercial; c) uma abordagem da Cláusula da Nação-mais-Favorecida e uma defesa do tratamento diferenciado que permitiam que os países em desenvolvimento dividissem com os países desenvolvidos os benefícios da liberalização sem fazer concessões no acesso a seus mercados; d) uma crença segundo a qual no período pós-colonial os países em desenvolvimento poderiam apelar para a benevolência dos países ricos; e) um pequeno volume relativo das exportações dos países em desenvolvimento que limitava sua influência nas negociações; f) uma pequena parcela de produtos manufaturados de suas exportações, o que significava barreiras comparativamente mais altas às suas exportações (WHALLEY \& HAMILTON, 1987, p. 5-6). Todos esses fatores eram comuns aos países em desenvolvimento, levando-os a trabalharem de maneira conjunta.

Agora uníssonos em torno de um discurso desenvolvimentista, eles pressionaram as potências comerciais por mudanças significativas, e por derrogações e concessões, no arcabouço jurídico do GATT no sentido de melhores especificações sobre a natureza peculiar das suas economias.

A inclusão da Parte IV em 1965 foi a resposta mais bem articulada nesse sentido. Esse instrumento jurídico refletia exceções às práticas usu- 
ais do regime. Dentre os diversos parágrafos do instrumento, um em especial chama nossa atenção, a saber, o artigo XXXVI, parágrafo $8^{\circ}$ que reza sobre a regra de reciprocidade: "The developed contracting parties do not expect reciprocity for commitments made by them in trade negotiations to reduce or remove tariffs and other barriers to the trade of less-developed contracting parties" (GATT, 1947, parte IV, art. XXXVI, $\S 8^{\circ}$ ). E ainda no Anexo I - Notas e Provisões Suplementares: "It is understood that the phrase 'do not expect reciprocity' means, in accordance with the objectives set forth in this Article, that the less-developed contracting parties should not be expected, in the course of trade negotiations, to make contributions which are inconsistent with their individual development, financial and trade needs, taking into consideration past trade developments" (GATT, 1947, Anexo I, adição ao art. XXXVI, $\left.\S 8^{\circ}\right)^{14}$.

Para nós esse parágrafo é sintomático, pois demonstra a capacidade dos países em desenvolvimento em articular, junto aos países ricos, uma exceção à regra central do regime: a reciprocidade. Ao serem excluídos da necessidade de barganhar de maneira recíproca, os países em desenvolvimento viram-se frente à possibilidade de galgarem concessões ainda mais amplas, como foi o caso da inclusão do Sistema Geral de Preferências ${ }^{15} 16$ em 1971 e da "Cláusula da Habilitação" de 1979.

\footnotetext{
14 Em inglês, no original. Respectivamente: "As partes contratantes desenvolvidas não esperam reciprocidade pelos compromissos assumidos por elas em relações comerciais para reduzir ou remover as tarifas ou outras barreiras ao comércio com partes contratantes menos desenvolvidas" e "Entende-se que a frase 'não esperam reciprocidade' significa, de acordo com os objetivos estabelecidos neste Artigo, que não se devem esperar, ao longo das negociações comerciais, das partes contratantes menos desenvolvidas, que façam contribuições que sejam inconsistentes com suas necessidades individuais de desenvolvimento, financeiras e comerciais, levando em consideração os desenvolvimentos comerciais passados" (N. E.).
}

15 Há bastante polêmica a respeito do SGP como um instrumento jurídico de ganhos para os países em desenvolvimento. $\mathrm{O}$ que seguidamente nota-se é a utilização do SGP, por parte dos países desenvolvidos, como medida de coerção. Ameaça-se fechar as preferências do SGP em relação a determinado país em desenvolvimento caso este não acate alguma demanda vista como importante pelo país rico. Aparentemente, concentrar os esforços no SGP é preservar as margens preferenciais ao invés de promover uma
A título de exemplo, na proposta brasileira apresentada à plenária em 1977, durante a Rodada Tóquio, o representante anunciava a necessidade das partes "estabelecerem algumas exceções à Cláusula da Nação-Mais-Favorecida" e proverem "um acordo básico e padrão ao SGP". O país solicitou "a não-reciprocidade como um direito dos países em desenvolvimento" (GATT, 1977). Tais propostas foram contempladas pela criação do Framework Group, um comitê de negociação que ficaria responsável, ao longo da Rodada Tóquio, por incluir as demandas dos países pobres. Com isso, o princípio do tratamento diferenciado ${ }^{17}$ foi incluído definitivamente no corpo de regras da instituição ao final da Rodada Tóquio.

A exclusão da reciprocidade para os países em desenvolvimento também refletia determinado movimento de mudança das regras. Segundo Finlayson e Zacher, antes da Rodada Kennedy, as negociações eram essencialmente bilaterais e centradas na redução de tarifas produto por produto (product by product). Assim, os países em desenvolvimento tinham menos a oferecer nas negociações graças ao tamanho reduzido e à pouca diversidade de suas economias. Com o advento de negociações sobre os códigos de barreiras não tarifárias (NTB Codes ${ }^{18}$ ) ao longo da Rodada Kennedy, o bilateralismo começou a ser permeado pelo multilateralismo, pois não se tratava mais de apenas produtos e mercados, mas também de regras internas ou questões de fronteiras, sobretudo as cotas (FINLAYSON \& ZACHER, 1983, p. 287). Depois que as tarifas per-

redução substancial por meio da Cláusula da Nação-maisFavorecida (GOLT, 1977, p. 19).

16 No entanto, na época de discussões sobre o SGP houve intensa crítica por parte dos EUA que via no instrumento perdas para suas exportações superavitárias em relação aos países em desenvolvimento. Devido a enormes pressões internacionais os EUA acabaram por aceitar a inclusão do SGP em seu arcabouço jurídico interno (ZEILER, 1991).

17 As provisões do Sistema Preferencial e Diferenciado (S\&D) eram: a renegociação de tarifas, embora não fosse legal dada a natureza liberal do Artigo XXVIII; as exceções à balança de pagamentos, emendadas em acordo de 1979 (Cláusula de Habilitação); as defesas das indústrias nascentes também previstas no acordo de 1979; a própria Cláusula de Habilitação de preferências comerciais e, por fim, os acordos específicos para os países em desenvolvimento via código regional (artigo XXIV).

18 Subsídios, valoração alfandegária, licença de importação, anti-dumping, direitos compensatórios e compras governamentais. 
deram importância na redução dos entraves, as cotas - limitações quantitativas à importação de determinado produto - surgiram como tema a ser tratado pelo regime (DAM, 2001, p. 90) ${ }^{19}$. Nesse sentido, a regra básica de reciprocidade sofreu abalos com o advento das negociações de tarifas lineares e NTB Codes nos anos 1960, uma vez que não havia mais concessões cruzadas facilmente quantificáveis. Além disso, os waivers de reciprocidade requeridos pelos países em desenvolvimento em 1965, o Sistema Geral de Preferências de 1971 e a "Cláusula de Habilitação" (GATT, 1979) dificultaram ainda mais o uso da norma em relação aos países em desenvolvimento (FINLAYSON \& ZACHER, 1983, p. 287-288).

No entanto, se por um lado os países desenvolvidos não podiam mais solicitar reciprocidade aos países pobres, por outro, continuavam a praticar a regra entre si, o que lhes garantia a condução das negociações e a produção de normas . Os acordos entre os grandes eram mais amplos e diversificados, definindo assim o conteúdo das regras das próximas negociações. De maneira contrária, os países em desenvolvimento, cientes de que os acordos firmados entre as potências por meio da regra de reciprocidade passavam ao largo de suas demandas, começaram a reclamar dos fracos resultados de negociações que não fossem baseadas na reciprocidade (FINLAYSON \& ZACHER, 1983, p. 289). E isso tinha certa lógica.

Como os países desenvolvidos estavam "proibidos" de buscar a reciprocidade nas negociações com os países em desenvolvimento, os ganhos com abertura de mercados para os últimos acabavam por ficar ainda mais reduzidos. Os países ricos passaram a ter parco interesse em barganhar com os países pobres, na medida em que estes possivelmente avocariam o tratamento diferenciado no momento de abertura de suas economias ${ }^{20}$. $\mathrm{O}$ raciocínio não revelado dos "caronas do comércio" era aderir às aberturas comerciais promovidas pelos e entre os grandes para, no instante de permitir

\footnotetext{
19 Segundo Baldwin, essa tendência tem origem na crescente utilização, por parte dos EUA, de restrições quantitativas para produtos agrícolas, petróleo, aço, têxteis de algodão e subsídios para estimular crescimento econômico e desenvolver novas tecnologias, comprovando assim uma atitude mais intervencionista do Estado americano na regulação da atividade econômica (BALDWIN, 1984, p. 18).
}

20 Na realidade, os interesses americanos em negociações a abertura de suas próprias economias, avocar o tratamento diferenciado sob o argumento da disparidade econômica e da infant industry.

O diplomata brasileiro George Maciel, envolvido nas negociações da Rodada Tóquio, sustenta que a escolha brasileira pela defesa do tratamento diferenciado, por exemplo, era a estratégia fundamental do país (MACIEL, 1986, p. 84-85). Nesse sentido, a forte crença na política de substituição das importações parece-nos a causa mais relevante para um posicionamento sob o guarda-chuva do tratamento diferenciado, principalmente para um país como o Brasil. Não era de interesse liberalizar e, sim, proteger. A regra do tratamento diferenciado era a defesa mais condizente com essa necessidade, em oposição à reciprocidade, via mais curta para a liberalização, porém mais inclinada às economias diversificadas das potências comerciais. A regra da reciprocidade e o princípio do tratamento diferenciado conflitavam.

Nesse sentido, entendemos, assim como Zacher e Finlayson, que a regra de reciprocidade assegura ganhos reais às economias mais capazes de colocar à mesa o maior número de temas $\mathrm{e}$ setores a serem negociados. Como a regra dita as reduções tarifárias e não tarifárias, o país que receber reduções ou concessões de outro para suas exportações deve conceder certa abertura para importações. No entanto, quando se avoca o tratamento diferenciado, as ofertas em direção aos países em desenvolvimento reduzem-se. E já que as potências possuem maiores mercados e são também os maiores parceiros comerciais, acabam conduzindo as negociações e refazendo as regras conforme suas demandas e ofertas (FINLAYSON \& ZACHER, 1983, p. 288), deixando de lado aqueles setores que não são de seu interesse liberalizar ${ }^{21}$.

\footnotetext{
Norte-Sul eram eminentemente secundários, fazendo com que suas ofertas em direção aos países da periferia fossem insuficientes. No caso dos resultados da Rodada Kennedy, por exemplo, graças à preponderância econômica dos EUA, os países em desenvolvimento foram prejudicados no que diz respeito ao acesso a mercados dos países ricos (ZEILER, 1991, p. 213).

21 É importante frisar ainda que Preeg sustenta a mesma idéia ao afirmar que os resultados da Rodada Kennedy foram um acordo entre as três grandes potências comerciais (PREEG, 1970, p. 227). Golt argumenta o mesmo sobre a Rodada Tóquio: uma barganha essencialmente triangular (EUA, Europa e Japão), com o Canadá e os países em desenvolvimento exercendo papéis pontuais (GOLT, 1979).
} 
No caso das barreiras não tarifárias a incidência da regra de reciprocidade não é tão clara, visto que não se negocia aspectos plenamente quantificáveis e sim regras gerais de conduta ${ }^{22}$. Entretanto, como o regime baseia-se em barganhas cruzadas, há uma ligação constante entre concessões tarifárias e regulação não tarifária. Barganham-se tarifas por regras mais amplas ou verticalizadas em questões de fronteiras (salvaguardas e anti-dumping), por exemplo.

Ora, como sabemos, a liberalização comercial implica em cortes lineares de tarifas e barreiras, via extensão da Cláusula da Nação-maisFavorecida (NMF), faceta multilateral e liberalizante do regime. No entanto, a prática de reciprocidade conflita com esse preceito na medida em que os países buscam um acordo pactuado por meio de concessões e demandas bilaterais antes de estendê-lo aos demais por meio da NMF. A vinculação do caráter liberal da NMF somente acontece depois da utilização da prática mercantilista. Em outras palavras, os acordos são feitos de maneira recíproca no plano bilateral para somente depois serem multilateralizados.

Como sustentamos ao longo do texto, quem não tiver o que oferecer vê diminuídas as possibilidades de equilíbrio no acordo. Desse modo, entendemos que a liberalização com base na reciprocidade tem sempre o viés dos mercados mais diversificados, ainda que as facetas multilateral e liberal sobressaiam no momento da implementação dos acordos. O pacto pretensamente equilibrado do multilateralismo é mitigado frente à prática bilateralista que promove o diferencial político e econômico entre os países.

Nesse sentido, a reciprocidade e sua característica mercantilista intrínseca refletem-se mais praticamente no fato de que, de acordo com Evans, raramente os países fazem concessões unilaterais. Até mesmo as tarifas sem grandes implicações econômicas são fichas de barganha nas trocas comerciais. Com essas fichas os países podem

\footnotetext{
22 Já que as partes não precisavam fazer concessões tarifárias sem acordos bilaterais e, portanto, com base na regra de reciprocidade, o princípio geral concernente às barreiras não tarifárias rezava que estas deveriam sofrer abolição imediata. No entanto, desde a inclusão das barreiras não tarifárias nas negociações da Rodada Kennedy os países procuraram reciprocidade para a abolição dessas práticas, embora o princípio de abolição devesse ter preferência sobre o princípio de reciprocidade (DAM, 1970, p. 19).
}

atrair os parceiros comerciais para a regra de reciprocidade sem ferir interesses econômicos relevantes (EVANS, 1971, p. 21-23). Tudo está na mesa para ser negociado. Alguns países conseguem transformar em fichas negociáveis até mesmo práticas ilegais. Por exemplo: determinado país aumenta os subsídios à exportação agrícola acima do permitido pelas regras do regime. A diminuição desse subsídio somente ocorrerá quando os demais países derem algo em troca, a despeito da ilegalidade da prática.

Enfim, a prática de reciprocidade adotada pelos países desenvolvidos, embora tenha como objetivo o fim dos entraves à livre circulação de mercadorias e serviços, na realidade mantém em voga um tipo de relação que tende a favorecer os países cujas economias são mais pujantes e diversificadas, pelo simples fato de que estas têm mais a oferecer e demandar que aquelas não tão complexas. $\mathrm{O}$ tratamento diferenciado servia, por um lado, como uma proteção para os países em desenvolvimento na medida em que impossibilitava uma postura totalmente recíproca dos países ricos em relação aos mercados dos pobres, pois se acreditava que uma barganha direta e recíproca entre ricos e pobres favoreceria os primeiros em qualquer circunstância; e, por outro, diminuía a liberalização de seus setores estratégicos (agricultura e têxteis), pois as propostas de abertura para os países que se enquadravam no tratamento diferenciado eram sempre escassas, promovendo assim a escalada tarifária e não tarifária setorial. Nesse sentido, o tratamento diferenciado propiciava duas lógicas conflitantes: a proteção a eventuais e desiguais aberturas dos mercados dos países pobres promovia apenas as suas exportações, mas essas mesmas exportações ficavam sujeitas a uma escalada tarifária e não tarifária por parte dos ricos, visto serem passíveis de barganhas cruzadas.

Cientes de seus ganhos, os países desenvolvidos não abandonaram a prática de reciprocidade e, com o passar do tempo, começaram a pressionar os países em desenvolvimento a adotar a mesma postura, a despeito do tamanho reduzido de suas economias. Quando o princípio do tratamento diferenciado foi questionado no decorrer da Rodada Uruguai, os países em desenvolvimento tiveram de repensar seus posicionamentos. Esse ambiente de contestação do tratamento diferenciado foi propiciado por um mandato negociador que representava um amplo processo de 
harmonização de políticas públicas. Porém, resta perguntar como esse questionamento foi construído e realizado.

\section{AHARMONIZAÇÃO INTERNACIONAL DE POLÍTICAS PÚBLICAS: DA RODADA TÓ- QUIO À RODADA URUGUAI}

O processo de harmonização de políticas públicas propiciado pela Rodada Uruguai teve início na Rodada anterior. A Rodada Tóquio foi marcada fundamentalmente pela ampliação da agenda comercial do regime, que até a Rodada Kennedy era restrita às questões de fronteiras (tarifas e cotas). Nesse sentido, Grieco afirma que a principal consecução da Rodada Tóquio foi o desenvolvimento de um amplo regime de barreiras não comerciais (NTB). Criaram-se os códigos de subsídios, antidumping, barreiras técnicas etc., enfim, uma gama de temas que significavam regulação de políticas públicas em âmbito global e não apenas barganhas tarifárias (GRIECO, 1990, p. 58).

A percepção de boa parte dos países em desenvolvimento sobre a Rodada Tóquio era de que os resultados das negociações em 1979 não eram satisfatórios e vários pontos ainda precisavam ser implementados. As negociações haviam feito progresso considerável na redução das barreiras tarifárias, mas não eram percebidas pelos países em desenvolvimento como uma grande vitória. Segundo Abreu e Fritsch, os cortes tarifários promovidos pela Rodada Tóquio não resultaram em uma maior harmonização das tarifas globais e nem foram espalhados e equilibrados por todos os setores. O próprio staff ${ }^{23}$ do GATT estimou que as reduções em produtos de interesse dos países em desenvolvimento foram menores do que os cortes nos produtos de interesse dos países ricos após o término da Rodada em 1979. Na realidade, boa parte dos produtos agrícolas foi excluída da redução tarifária, assim como produtos industrializados tidos como "sensíveis": têxteis e calçados. De maneira geral, os produtos que enfrentavam tarifas mais altas eram exatamente aqueles não cobertos por concessões recíprocas (ABREU \& FRITSCH, 1987, p. 114-115), promovendo assim picos tarifários em setores estratégicos para

23 Hudec demonstra em interessante análise o papel determinante do staff do GATT na condução das negociações, mais especificamente do órgão de solução de controvérsias. O papel do staffé tema geralmente esquecido pela literatura especializada (HUDEC, 1998, p. 101-120). os países em desenvolvimento. A Rodada Tóquio era percebida, portanto, como o início de uma escalada tarifária setorial.

Outro aspecto que também preocupava os países em desenvolvimento era o recrudescimento do comércio controlado por meio de barreiras não tarifárias. É importante lembrar que houve na década de 1970 um vertiginoso crescimento do uso das barreiras não tarifárias pelos países ri$\cos ^{24}$. Além disso, ocorreu no período uma mudança qualitativa nos tipos de barreiras protecionistas no mundo desenvolvido. Os Voluntary Export Restraints (VERs) e outras salvaguardas seletivas começaram a permear o comércio entre as nações, sobretudo dos países ricos em relação aos países da periferia. Segundo Hamilton e Whalley, desde a Rodada Kennedy ocorria uma internacionalização da legislação corretiva dos EUA por meio da elevação do uso de proteções contingenciais (anti-dumping, salvaguardas e medidas compensatórias) (WHALLEY \& HAMILTON, 1987, p. 6$)^{25}$.

No entanto, a Rodada Tóquio ocorreu em um momento histórico no qual os países do então chamado Terceiro Mundo conseguiam ter mais influência nas decisões multilaterais do sistema

\footnotetext{
24 Entre 1974 e 1980 o comércio, sujeito a barreiras não tarifárias, cresceu de $36,2 \%$ para $45,8 \%$ de todo o comércio dos EUA, de $35,8 \%$ para $44,8 \%$ de todo o comércio europeu e de $56,1 \%$ para $59,4 \%$ de todo o comércio japonês. Acreditamos que o fato desse protecionismo ter crescido exatamente quando as exportações de manufaturados dos países em desenvolvimento começavam a crescer acabou por diminuir a possibilidade de inserção dos bens industriais dos países pobres nas correntes do comércio mundial. Em 1979 a parcela das exportações industriais provenientes dos países em desenvolvimento, sujeita a barreiras não tarifárias nos países da OCDE, era de $30 \%$, enquanto entre os próprios países da organização era de $11 \%$ (ABREU \& FRITSCH, 1987, p. 187).

25 Vários fatores explicam o recrudescimento do protecionismo. No entanto, um aspecto parece-nos importante: o declínio da preponderância econômica dos EUA nos anos 1970 e início dos anos 1980. Os problemas decorrentes desse declínio mostravam, de acordo com Lipson, que não só a hegemonia estadunidense estava em crise, mas abalado também estava o consenso do período posterior à II Guerra Mundial em torno da liderança isolada dos EUA na área comercial. Diversos países, principalmente o Japão, a Alemanha e alguns países em desenvolvimento ameaçavam setores pouco competitivos da economia norte-americana, notadamente os intensivos em mão-de-obra (LIPSON, 1983, p. 257).
} 
internacional. Segundo Golt, não havia sequer uma frase e com certeza nenhum parágrafo no mandato negociador da Rodada Tóquio que não contivesse uma referência à posição especial ou aos problemas econômicos dos países em desenvolvimento. Havia referências claras ao tipo de reciprocidade esperada dos países do Terceiro Mundo e o reconhecimento explícito ao tratamento diferenciado (GOLT, 1977, p. 2). Tudo isso provava que as questões terceiro-mundistas estavam no centro das atenções mundiais durante a década de 1970; e, obviamente, os países em desenvolvimento não queriam perder esse status privilegiado.

Para explicar esse contexto, Golt identificou um paradoxo interessante na Rodada Tóquio. Por um lado, procurava-se garantir certas preferências para os países mais pobres e, por outro, tentava-se regular o uso de certos instrumentos, principalmente barreiras não tarifárias, a fim de coibir a enxurrada de produtos provenientes dos países em desenvolvimento nos mercados dos países ricos, notadamente nos EUA (idem, p. 30). Criaram-se assim duas lógicas distintas que geraram mecanismos conflitantes dentro da Rodada. Esses dois processos pressionavam os países em desenvolvimento a aumentarem a força do primeiro e coibirem a incidência do segundo. Era fundamental que o tratamento diferenciado fosse ampliado e as barreiras não tarifárias, principalmente as VERs, fossem eliminadas antes de qualquer nova Rodada. Se o tratamento diferenciado era a defesa contra a reciprocidade e, conseqüentemente, contra a abertura comercial indesejada, a inoperância da reciprocidade em relação aos países pobres propiciava a ascensão das VERs.

Agora, conforme colocamos, a despeito do grande problema comercial que as barreiras não tarifárias causavam, a Rodada Tóquio é geralmente vista pelos especialistas como um momento representativo da influência dos países em desenvolvimento no GATT, ao contrário das percepções dos países à época. Nesse sentido, é importante frisar que as normas do mecanismo de tomada de decisões da Rodada Tóquio favoreciam os países em desenvolvimento. Mas como esse processo funcionava?

De acordo com Grieco, para cada código negociado (anti-dumping, salvaguardas, subsídios etc.) era estabelecido um Comitê de Assinantes ao final da Rodada. Esse comitê servia como um mecanismo institucional, por meio do qual os signatários podiam verificar a implementação dos códigos e, eventualmente, autorizar retaliações contra a parte que não estivesse respeitando as regras (GRIECO, 1990, p. 59).

No entanto, mesmo após ter participado das tratativas ao longo da Rodada, o país em questão não era obrigado a assinar o código e, conseqüentemente, fazer parte do Comitê. Os temas eram discutidos em separado e, ao final, podiam ou não ser assinados pelos negociantes. Dessa forma, o país que se sentisse ameaçado em seu interesse poderia não assinar o código, mesmo tendo participado ativamente de sua negociação, e não se veria obrigado a participar do Comitê de Assinantes. Ato contínuo, não seria obrigado a internalizar as regras do código, sendo impossibilitado, portanto, de sofrer retaliações. Se por um lado, isso diminuía o poder vinculante das regras, por outro, permitia uma maior margem de manobra aos países que mantinham um arcabouço protecionista com o objetivo de promover o desenvolvimento, como era o caso dos defensores da política de substituição de importações.

De acordo com Steinberg, as normas da Rodada Tóquio definitivamente favoreceram os países em desenvolvimento, que acabaram recebendo todos os direitos dos códigos de subsídios e anti-dumping - visto que os países ricos acabaram por internalizá-los, estendendo assim os benefícios a todos - mas não foram obrigados a assinar as obrigações contidas nos acordos. Quando os países em desenvolvimento perseguiram essa estratégia no final dos anos 1970, muitos diplomatas norte-americanos, diz o autor, ficaram preocupados com a possível ameaça ao equilíbrio da política comercial dos EUA, que estava entre oferecer tratamento diferenciado e atender as demandas internas por reciprocidade dos parceiros comerciais. Estes diplomatas temiam a "UNCTADização" do GATT (STEINBERG, 2002, p. $357-358)^{26}$. Sendo assim, parece-nos claro que

\footnotetext{
26 Diebold Jr. argumenta que a retórica estadunidense de defesa do tratamento diferenciado e das demandas terceiromundistas deveria ser comparada à realidade de elaborados acordos restritivos em têxteis, um dos poucos produtos manufaturados exportados em quantidade pelos países em desenvolvimento. Isso por si só provaria um descompasso entre a retórica e a realidade (DIELBOLD JUNIOR, 1967, p. 299).
} 
a Rodada Tóquio, ainda que discriminatória em certos produtos e tarifas, permitiu uma maior autonomia decisória para os países em desenvolvimento exatamente porque tais países não se viam comprometidos em acatar as obrigações contidas nos códigos, pois apenas usufruíam os ganhos da abertura alheia.

Na Rodada Uruguai, contudo, esse contexto de favorecimento às estratégias de protecionismo dos países em desenvolvimento caiu por terra. $\mathrm{O}$ significado da nova Rodada que se pretendia iniciar em 1982 feria a autonomia dos países mencionados por vários motivos, mas dois aspectos são mais significativos: a harmonização das políticas públicas em nível internacional e a crítica aos "caronas do comércio".

A proposta estadunidense apresentada na Reunião Ministerial de 1982 em Genebra contempla três novas áreas: propriedade intelectual, serviços e investimentos relacionados ao comércio, que não seriam cobertas por cotas ou tarifas, mas representavam a construção de um corpo de regras único de âmbito global ${ }^{27}$. Nas palavras de Ricupero, os países da OCDE alegavam que uma produção tendencialmente internacionalizada precisava de uma legislação também internacionalizada. $\mathrm{O}$ ciclo de trocas comerciais limitadas às questões de fronteiras (tarifas e cotas) estava exaurido e o momento de uma integração mais profunda havia chegado (RICUPERO, 1998, p. 13).

Nesse sentido, os países em desenvolvimento estariam sujeitos, por um lado, a acatarem um corpo de regras único negociado em Genebra para setores tradicionalmente protegidos; e, por outro, a aceitarem a redução de suas prerrogativas sob o tratamento diferenciado por meio da aceitação de amplas disciplinas em serviços, propriedade intelectual e investimentos, questões até então não previstas no GATT. Esse processo que a Rodada promovia, segundo Tussie, englobava um movimento de aproximação do GATT aos regimes reguladores preferidos e aplicados pelos maiores demandantes no comércio mundial, os EUA (TUSSIE, 1993, p. 70).

\footnotetext{
27 No comércio de serviços, por exemplo, as cotas e tarifas são raras. As barreiras comerciais são derivadas da regulação doméstica; daí a idéia de harmonização de políticas públicas de âmbito global. Os novos temas atingem a capacidade e a margem de manobra do Estado em regular as atividades econômicas (DAM, 2001, p. 92).
}

Tussie alerta que, se a criação de um único nível de harmonização é levada ao extremo, a principal implicação disso reside no fato de que, se as economias não são similares, dificilmente se engajarão em trocas comerciais de maneira equilibrada (idem, 1993, p. 77). O comércio até pode ser livre, mas não eqüitativo. Há um nítido descompasso entre regras únicas e economias desiguais. As exceções serviam para abrandar a aplicabilidade de um corpo jurídico unificado em tarifas e barreiras não tarifárias sobre um conjunto econômico díspar, embora permitissem que as reduções tarifárias às economias protegidas fossem menores. Ato contínuo, a diminuição de sua incidência acarretaria um aumento de obrigações com perdas para as economias mais frágeis do sistema. Segundo Tussie, ao contrário das rodadas anteriores, portanto, o mandato negociador da Rodada Uruguai envolveria discussões sobre política doméstica, práticas institucionais e regulações em grau sem precedentes. Pela primeira vez, a harmonização de práticas domésticas tornar-se-ia uma proposição internacionalmente negociada (idem, 1993, p. 70).

Os EUA entendiam que a inclusão de propriedade intelectual, investimentos e serviços propiciariam ganhos consideráveis à sua economia, mais competitiva nas três áreas. Além disso, Ricupero alega que os países da OCDE sustentavam a introdução dos novos temas sob a alegação de que a diminuição das tarifas como fator dinâmico das trocas comerciais forçaria a inclusão de novas áreas da economia mundial no regime comercial - áreas essas que sofriam com a falta de regulações multilaterais (RICUPERO, 1998, p. 12). Logo, na visão estadunidense, a fim de prevenir a erosão do sistema, o escopo das obrigações do GATT precisava ser estendido e os caronas coibi$\operatorname{dos}^{28}$.

\footnotetext{
28 No que diz respeito à crítica aos "caronas" do comércio é interessante o aspecto ressaltado por Hirst e Lima sobre o Brasil. De acordo com as autoras, a percepção norteamericana da posição brasileira no sistema internacional variou da aceitação do Brasil como um "país-chave" na região latino-americana durante a década de 1970, momento do crescimento econômico vertiginoso do país, para a condição de "carona" na década de 1980, momento em que as exportações brasileiras se expandiam e tornavam mais complexas. O Brasil passou a ser "enquadrado" como um daqueles países que eram favorecidos pelas regras do comércio e a crítica norte-americana, aliada ao seu aparato institucional (Seção-301), voltou-se contra Brasília (LIMA \& HIRST, 1994, p. 45-46).
} 
Nas palavras de Preeg, a iniciativa de lançar uma nova Rodada foi exclusiva do executivo norte-americano, que teve de convencer não só o Congresso do país, mas também os parceiros da Aliança Atlântica. A administração Reagan havia iniciado seus trabalhos em 1981 intitulando-se liberalizante. O Congresso, por sua vez, estava suscetível às pressões protecionistas que eventualmente eclodiriam devido à percepção generalizada de estagnação econômica mundial (PREEG, 1995, p. 29). Era preciso conter a onda protecionista e a administração Reagan via uma nova Rodada com temas que representavam setores competitivos dos EUA como a melhor saída ${ }^{29}$.

Nesse contexto, havia um consenso e uma divergência dentro da Aliança Atlântica. No que diz respeito à necessidade de coibir os "caronas" a convergência era certa. A Europa e os EUA pressionavam por mudanças nas responsabilidades dos países em desenvolvimento na área comercial. A questão dos "caronas" estava ligada, contudo, aos temas tradicionais (questões de fronteiras), herança da Rodada Tóquio. Nesse ponto os EUA e a Comunidade Européia pressionam, portanto, por

29 Em junho de 1982 a imprensa já registrava o início da polarização entre os EUA e alguns países em desenvolvimento, especialmente o Brasil, no tocante ao lançamento da nova Rodada. A iniciativa norte-americana de trazer os novos temas para dentro do arcabouço do GATT gerava protestos dos países que ainda defendiam uma instituição que tratasse apenas do comércio de bens e buscasse resolver as questões pendentes das rodadas anteriores: "The United States had originally sought to launch 'negotiations' on investment and trade in services through the ministerial meeting. Subsequently, it lowered its sights and since then has been seeking studies to be completed by 1983 and for actions on them by the Contracting Parties at their 1983 annual meeting. When the United States originally broached the idea, it had received support of sorts from some of the industrialized countries while Brazil and one or two other Third World countries had opposed it, arguing the subjects were beyond the competence of GATT" (US MOVES ON TRADE, 1982) [“'Os Estados Unidos originalmente procuraram lançar 'negociações' sobre investimentos e comércio de services por meio da reunião ministerial. Subseqüentemente, eles baixaram suas expectativas e desde então têm procurado estudos a serem completados em 1983 e ações sobre elas, pelas partes contratantes, em sua reunião anual de 1983. Quando os Estados Unidos originalmente propuseram para discussão a idéia, ela teve o apoio de alguns países industrializados, enquanto o Brasil e um ou dois outros países do Terceiro Mundo opuseram-se a ela, argumentando que esses temas estavam fora da competência do GATT" - N. E.]. alterações em regras já existentes, ou seja, buscavam a construção corretiva das regras (GRIECO, 1990, p. 103). A implicação maior disso era a diminuição da preponderância do tratamento diferenciado não apenas em temas tradicionais, mas também nos novos temas. Se os países em desenvolvimento não mais poderiam avocar o tratamento diferenciado em eventuais reduções tarifárias, não caberia também avocá-lo nos novos temas, visto que não se tratavam mais de simples concessões cruzadas passíveis de quantificação.

Ao contrário, os novos temas teriam um corpo de regras unificado que não permitiria a existência de concessões ou derrogações. No subtema de prazos do usufruto de patentes, isso fica claro. Enquanto os EUA e a Comunidade Européia (CE) exigiam um prazo de 20 anos de utilização da patente após o registro, os países em desenvolvimento solicitavam que o prazo fosse definido por legislações nacionais e não por legislação internacional unificada (STEWART, 1993, p. 114). Para as potências comerciais não haveria possibilidade de concessão às legislações nacionais nesse ponto. Aos países pobres não haveria mais como solicitar exceções.

Ora, o fim do tratamento diferenciado, conforme colocamos anteriormente, faria com que as obrigações dos países em desenvolvimento fossem ampliadas pela necessidade de acatar regras já existentes ${ }^{30} 3132$. Os países ricos não preten-

30 Em declaração sobre a necessidade de lançar a Rodada
na reunião da OCDE em maio de 1982, o representante
norte-americano anunciava que os países em desenvolvi-
mento deveriam aumentar seus comprometimentos ao re-
gime: "One idea I would like you to consider is a new
round of trade negotiations within the GATT involving
exchange of preferential tariff concessions by developed
countries for developing countries whose products have
been graduated out of GSP in return for increased
commitments by these developing countries on the
reduction of tariff and non-tariff barriers to their markets"
(PREEG, 1995, p. 32) [“Uma idéia que gostaria que você
considerasse é uma nova rodada de negociações comerciais
no âmbito do GATT, envolvendo a troca de concessão de
preferências tarifárias dos países desenvolvidos para os
países em desenvolvimento, cujos produtos tenham sido
classificados fora do SGP, em retribuição aos crescentes
compromissos desses países em desenvolvimento na redu-
ção das barreiras tarifárias e não-tarifárias aos seus merca-
dos" - N. E.].
31 É importante lembrar que a crítica aos "caronas" tam-
bém tinha uma razão mercadológica e não apenas jurídica. 
diam revolucionar as regras tradicionais, apenas ampliá-las ou reconstruí-las de modo a atingir todos os membros. Por conseguinte, a invalidação do tratamento diferenciado significava reformas efetivas na estrutura política e econômica dos países em desenvolvimento, pois a própria iniciativa de sustentar a política de substituição das importações significava não acatar a totalidade das regras dos temas tradicionais e permitir proteções setoriais de produtos tradicionalmente regulados (bens industriais).

Já no que diz respeito à inclusão dos novos temas na agenda, havia divergências entre os países ricos e entre ricos e pobres. A falta de consenso propiciava a constituição de declarações vagas acerca de inclusão e encaminhamento dos três temas. Um corpo de regras novo deveria ser criado a partir de frouxas e inconsistentes declarações políticas ocorridas em Punta del Este na Reunião Ministerial de $1986^{33}$.

Desse modo, acreditamos que o lançamento da Rodada acabou por promover o início de um processo de liberalização dos países em desenvolvimento que caminharia sobre dois trilhos. De um lado, o fim das exceções às questões de fronteiras, ligadas ao ataque frontal ao tratamento diferenciado; e de outro, uma tentativa de harmonização de legislações nacionais dentro de um único arcabouço jurídico internacional, o que acarretava a impossibilidade de avocação de um eventual tratamento diferenciado. Não seria inusitado pensar, portanto, que esse duplo ataque

Nos anos 1970 as exportações dos países em desenvolvimento não incomodavam as potências comerciais. Nos anos 1980 esse cenário foi alterado pelo boom de diversos setores econômicos dos países pobres. Para os EUA estes países deveriam acatar as regras da mesma forma, uma vez que já começavam a competir em igualdade de condições (TUSSIE \& LENGYEL, 2003, p. 486).

32 Os EUA estavam interessados em redefinir os parâmetros das obrigações. Para os EUA continuarem a ter seu mercado aberto era fundamental que os demais países, sobretudo aqueles que avocam o tratamento diferenciado, também abrissem suas economias às exportações americanas. O lema era fair trade, not free trade ) ("comércio justo, não comércio livre”) (MACLAREN, 1998, p. 184).

33 Os novos temas foram contemplados, assim como os demais, com poucos parágrafos, porém, dada a ausência de negociações anteriores e o conflito de interesses entre os membros, as declarações eram mais vagas e imprecisas do que os temas tradicionais, os quais faziam referência a acordos anteriores (GATT, 1986). fragilizou sobremaneira o posicionamento dos países em desenvolvimento.

Ora, as opções de criar estratégias autônomas de inserção no GATT ficaram bastante restritas em decorrência desse processo. $\mathrm{O}$ advento dos novos temas na estrutura jurídica do GATT tornou-se o momento da mudança no padrão de diplomacia dos países em desenvolvimento. Caso fossem imediatamente incluídos no GATT, a capacidade dos países em desenvolvimento de formular políticas públicas de desenvolvimento seria ameaçada, não porque tais políticas dissessem respeito às áreas de serviços ou investimentos apenas, mas sim porque os novos temas englobavam uma regulação jurídica de ordem doméstica para ter efeito. Era essa "ingerência" nos assuntos internos que certos países em desenvolvimento combatiam.

A título de exemplo, o posicionamento brasileiro no período que antecedeu a Rodada Uruguai refletia em grande medida essa atitude de cautela. Em texto apresentado ao GATT em 23 de junho de 1986, véspera do lançamento da Rodada, o Brasil deixava clara sua intenção de não aderir à prática da reciprocidade. Nota-se na passagem a seguir a preocupação pontual da crise da dívida externa: "Developed countries do not expect reciprocity and they shall not seek nor shall LDC's be required to make concessions that are inconsistent with the latter's development, financial and trade needs. In this context developed countries shall give particular consideration to problems of foreign debt, poverty and the critical economic situation of developing countries"34 (GATT, 1986a, p. 9).

Além disso, a análise de Flávia de Mello também sustenta a preocupação do Brasil com o novo mandato. Em documento da Divisão Comercial do Itamaraty de novembro de 1987, a autora aponta a passagem em que o país defendia que os novos temas "constituem a área de preocupação central do Brasil na Rodada Uruguai" e na qual "o

\footnotetext{
34 Em inglês, no original: "Os países desenvolvidos não esperam reciprocidade e eles não a procurarão, nem se deve exigir dos países menos desenvolvidos que façam concessões que são inconsistentes com as necessidades de desenvolvimento, financeiras e comerciais dos últimos. Nesse contexto os países desenvolvidos devem ter particular consideração para os problemas da dívida externa, da pobreza e da crítica situação econômica dos países em desenvolvimento" (N. E.).
} 
principal objetivo brasileiro é preservar seu raio de manobra em termos de regulamentação nacional" (MELLO, 1992, p. 86). Como vimos, a aceitação dos novos temas significava a diminuição da capacidade nacional de legislar, uma vez que implicaria na internalização de um arcabouço de regras de caráter internacional.

Nos anos que antecederam a Rodada, era importante para os países em desenvolvimento conter o ímpeto norte-americano, mas também era fundamental resolver questões pendentes. No início da década de 1980 a posição do G5 (Brasil, Índia, Argentina, Iugoslávia e Egito) no GATT, antes de apoiar o lançamento de uma nova Rodada dentro dos moldes apresentados pelos EUA, era a de solucionar algumas lacunas dos acordos firmados na Rodada anterior. Os temas defendidos pela plataforma do G5 em 1982 eram: assegurar a implementação dos códigos da Rodada Tóquio antes do lançamento de uma nova Rodada; não iniciar outra Rodada sem antes resolver satisfatoriamente velhas questões (agricultura e têxteis); obter dos países desenvolvidos a garantia de que não aumentariam as tarifas no curso da negociação (stand-still); alcançar a abolição de todas as práticas comerciais que fossem contra as regras do GATT antes do lançamento da Rodada (roll-back) e não discutir os novos temas enquanto os antigos não fossem resolvidos.

Entretanto, o mandato negociador apresentado pelos EUA no início dos anos 1980 não contemplava essas demandas. Como vimos, a proposta norte-americana enfatizava a harmonização de políticas públicas em nível global e não a solução dos anseios desenvolvimentistas que vinham da Rodada Tóquio. E a mera possibilidade de uma nova Rodada que não tivesse como foco o tratamento das questões pendentes e que aparentemente regesse sobre a formulação de políticas públicas fugia aos interesses da maioria dos países em desenvolvimento. A oposição começava a ser construída.

Um ambiente radicalizado dessa maneira - países desenvolvidos e em desenvolvimento cerrando fileiras em campos opostos - indicava percepções bastante diferenciadas acerca do encaminhamento da nova Rodada. O embate resumia-se à ampliação da reciprocidade em temas tradicionais e à busca da ampliação do processo de harmonização de políticas públicas, de um lado, e a defesa do tratamento diferenciado e preserva- ção da capacidade de regulação nacional, de outro. Essas visões entraram em choque nas reuniões que antecederam o lançamento entre a Reunião Ministerial de 1982 em Genebra e a Reunião Ministerial de 1986 em Punta del Este. As negociações da nova Rodada adentraram de forma antagônica até pelo menos a aceitação, por parte dos países em desenvolvimento, da plataforma apresentada pelos países ricos, em especial a proposta estadunidense. Esse processo foi intensamente marcado pela coerção e pactuação assimétrica das regras e normas do regime. A fim de entendê-lo é necessário reconstruir as fases e as estratégias desse embate.

\section{O PROCESSO NEGOCIADOR DA RODA- DAURUGUAI}

Hamilton e Whalley já sustentavam em 1987 que o encaminhamento da Rodada da forma como estava, aliada aos interesses cada vez mais distintos e concretos dos países em desenvolvimento acarretaria em um posicionamento mais recíproco por parte dos mesmos (WHALLEY \& HAMILTON, 1987, p. 6).

A Coréia do Sul já destoava dos demais ao apoiar o lançamento de uma nova Rodada nos moldes da proposta dos EUA ${ }^{35}$. A primeira defecção de peso da grande coalizão dos países em desenvolvimento que ecoava das declarações conjuntas na UNCTAD: "When the United States originally broached the idea, it had received support of sorts from some of the industrialized countries while Brazil and one or two other Third World countries had opposed it, arguing the subjects were beyond the competence of GATT. Excepting for South Korea that supported consideration of the 'trade in services' issue, a large number of Third World countries are however reported to have spoken out in opposition to the US move" 36 (US MOVES ON TRADE, 1982).

35 A Coréia do Sul não tinha objeções à vinculação entre serviços e bens e apoiava abertamente a agenda estadunidense (KIHWAN \& SOO, 1989, p. 162).

36 Em inglês, no original: "Quando os Estados Unidos originalmente propuseram a idéia, ela recebeu o apoio de vários dos países industrializados, enquanto o Brasil e um ou dois outros países do Terceiro Mundo opuseram-se a ela, argumentando que os temas estavam além da competência do GATT. Exceção feita da Coréia do Sul, que apoiou a consideração do tema do 'comércio de serviços', um grande número de países do Terceiro Mundo, todavia, deixaram clara sua oposição à manobra dos Estados Unidos" (N. E.). 
No entanto, para entender essa mudança duas perguntas devem ser feitas - os países em desenvolvimento rumaram à reciprocidade porque entendiam ser este o melhor caminho para o desenvolvimento frente a um mundo cada vez mais integrado? Ou ficaram sem alternativas face ao conteúdo e à forma das negociações ao longo da Rodada Uruguai, adotando assim a prática de reciprocidade a contragosto? Talvez uma possível resposta para as indagações resida em uma análise mais detalhada do procedimento de tomada de decisões utilizado na Rodada Uruguai em contraste com as Rodadas anteriores, em especial com a Rodada Tóquio.

Nesse sentido, Steinberg lembra que as instituições internacionais ${ }^{37}$ usam combinações de formas procedimentais para a tomada de decisões, a saber, voto majoritário, voto com peso e voto de igualdade soberana (consenso). O GATT usa tradicionalmente o voto de igualdade soberana. Tendo isso em mente, o autor elabora uma pergunta interessante: por que os países desenvolvidos, a despeito de sua superioridade econômica, preferiram utilizar o voto de igualdade soberana nas reuniões de uma entidade tão importante como o GATT e não o voto com peso, como utilizado no FMI (STEINBERG, 2002, p. 340)? Com economias de maior peso, os países desenvolvidos poderiam impor suas vontades com base em um sistema de votação que levasse em consideração esse diferencial. No entanto, esse nunca foi o caso no GATT. Por quê?

Para compreender as razões dessa opção Steinberg conceitua duas modalidades de barganha: law-based e power-based. Expliquemos. Quando a barganha é law-based os países seguem rigorosamente as regras a fim de buscar um consenso por meio de contratos de abertura de mercados aproximadamente simétricos. Já quando ocorre uma barganha de tipo power-based, os países utilizam instrumentos de poder extrínsecos às regras, atribuindo o peso invisível ${ }^{38}$ de suas economias ao processo de tomada de decisões.

\footnotetext{
37 Esse termo refere-se a instituições intergovernamentais. No caso das instituições que caminham para supranacionalidade (União Européia), as regras procedimentais têm caráter diferenciado.

38 O peso invisível das economias significa o reconhecimento dos países-membros sobre o tamanho da economia de determinado país. Por mais que o voto no processo de
}

Geram-se assim resultados mais assimétricos, normalmente em prol dos países desenvolvidos.

Segundo o autor, um processo de tomada de decisões com base na igualdade soberana gera uma gama de informações sobre as preferências dos países que facilita a formulação de pacotes legislativos que favorecem os interesses dos mais poderosos. Exatamente por ser votado por consenso esse pacote é aceito como legítimo pelos demais $^{39}$. Mas como podemos explicar com mais precisão esse processo?

Patterson e Patterson (apud STEINBERG, 2002 , p. 344) argumentam que a regra de consenso tornou-se prática usual do GATT por volta dos anos 1950, quando os membros começaram a admitir um grande número de países em desenvolvimento por conta do contexto de luta contra o bloco soviético. Com receio de que os novos países pudessem formar coalizões e barrar os in-

tomada de decisões não tenha peso como no caso do FMI, os países reconhecem o tamanho das economias uns dos outros e calculam sua estratégia e posicionamento em relação a esse peso, chamado por Steinberg de invisível. Por não ser levado em consideração juridicamente, já que cada país tem apenas um voto, o peso das economias acaba por influir de maneira indireta, porém decisiva nas negociações.

39 No documento de fundação do regime - GATT-1947 não se encontra menção sobre a regra de consenso, pelo contrário, as regras do processo de tomada de decisões lá explicitadas são de maioria simples e dois terços para casos excepcionais definidos pelas partes. Os parágrafos $3^{\circ}, 4^{\circ} \mathrm{e}$ $5^{\circ}$ do Artigo XXV não abrem espaço a dúvidas: "3. Each contracting party shall be entitled to have one vote at all meetings of the CONTRACTING PARTIES"; "4. Except as otherwise provided for in this Agreement, decisions of the CONTRACTING PARTIES shall be taken by a majority of the votes cast"; "5. In exceptional circumstances not elsewhere provided for in this Agreement, the CONTRACTING PARTIES may waive an obligation imposed upon a contracting party by this Agreement; Provided that any such decision shall be approved by a two-thirds majority of the votes cast and that such majority shall comprise more than half of the contracting parties" (GATT, 1947) ["3. A cada parte contratante será conferido possuir um voto em todas as reuniões das PARTES CONTRATANTES"; "4. Exceto pelo que for disposto neste Acordo, as decisões das PARTES CONTRATANTES serão tomadas pela maioria dos votos"; "5. Em circunstâncias excepcionais, não previstas em nenhuma parte deste Acordo, as PARTES CONTRATANTES podem desistir de uma obrigação imposta a uma parte contratante por este Acordo, desde que qualquer decisão desse tipo seja aprovada por maioria de dois terços dos votos e que tal maioria compreenda mais da metade das partes contratantes" - N. E.]. 
teresses dos países ricos por meio das regras de maioria simples ou dois terços, já que nesses casos os mais poderosos não precisariam ser consultados devido ao grande número de países pobres, a prática de consenso acabou sendo adotada, provavelmente pela pressão dos países desenvolvidos. Daquele momento em diante todas as decisões deveriam ter a anuência dos EUA, da CE e do Japão.

É importante frisar que dificilmente seria introduzido no GATT o voto por peso, sob pena de os países que votassem contra determinada medida, provavelmente os mais pobres, não introduzirem as regras ${ }^{40}$. Além disso, o enfraquecimento das regras não seria salutar para a manutenção do regime no longo prazo. Com o voto de consenso, todos os países se sentiriam obrigados a seguirem as regras acordadas, em última instância por eles mesmos.

De acordo com Velasco e Cruz (2005, p. 43), na ausência de laços de solidariedade mais sólidos entre os participantes do processo decisório, o consenso surge como expediente adequado para assegurar o apoio necessário à implementação da decisão coletiva. Recorrer ao mecanismo de consenso é optar, segundo o autor, por uma solução de compromisso. Já para Winham, enquanto os países em desenvolvimento precisam de quaisquer vantagens concedidas dos países desenvolvidos a fim de promoverem as exportações, os países ricos necessitam dos países pobres para dar ao regime um caráter universal (WINHAM, 1986, p. 142). O caráter coletivo do compromisso traz legitimidade à instituição.

Barry Buzan afirma, por sua vez, que o sistema de consenso garante que a tomada de decisões na negociação multilateral de um tratado não será dominada pela superioridade numérica de nenhum grupo de nações. Antes, fica mais claro o

\footnotetext{
40 A lógica de funcionamento do voto com peso que ocorre no FMI, por exemplo, é operacionalizada com certa facilidade porque os países com economias menores normalmente são os tomadores de recursos da instituição. O não comprimento das condicionalidades do empréstimo faz com que o país não mais receba recursos no futuro. No GATT, as decisões envolvem apenas regulações e não concessão de recursos. O país precisa ter consciência de que a decisão tomada na plenária foi sua própria decisão, caso contrário vê-la-á como uma imposição e, provavelmente, não a aplicará internamente.
}

diferencial de poder das nações. $\mathrm{O}$ método de consenso permite a manutenção de uma processualística igualitária que, na prática, assegura que as negociações reflitam o poder das nações participantes (BUZAN, 1981, p. 327).

Desse modo, os países desenvolvidos conseguiram fazer com que todas as decisões passassem por suas mãos, aumentando assim seu poder de barganha, a despeito do pequeno número de votos. Portanto, ao contrário do que geralmente se pensa, a regra de consenso acaba por diminuir o poder de barganha dos países em desenvolvimento e aumentar o poder dos países ricos, principalmente em contextos em que o peso invisível de suas economias tem presença marcante.

Mas como o consenso pôde ser alcançado ao longo da Rodada Uruguai com interesses tão distintos entre desenvolvidos e em desenvolvimento? Segundo Steinberg, devido à força da regra de unanimidade, as negociações procuram alcançar uma fórmula que possa ser aceita por todos, forçando uma aproximação de interesses e percepções. No entanto, é possível apenas para as grandes potências respeitar as regras procedimentais e, simultaneamente, usar práticas extrínsecas ao regime a fim de livrarem-se das restrições ao uso do poder aparentemente simétrico ao corpo de regras (STEINBERG, 2002, p. 345).

Uma dessas práticas é o fechamento e abertura de mercados. Mesmo que a barganha tome a forma de promessas mútuas de abertura de mercados, os países desenvolvidos (grandes mercados) são mais dotados em negociações comerciais. A implicação política disso, segundo Steinberg, é que um dado volume de liberalização oferece proporcionalmente menos benefícios políticos domésticos para governos de grandes economias do que para os de pequenas (idem, p. 347). Desse modo, de acordo com Baron e Ferejohn, países em desenvolvimento são mais impacientes para alcançar um acordo de liberalização do que grandes economias, uma vez que dependem muito mais da abertura que os países ricos (BARON \& FAREJOHN, 1989). Os impactos de uma abertura comercial em economias mais diversificadas podem diluir-se em meio aos diversos e pujantes setores econômicos do país. Já uma abertura comercial às economias dos países menos desenvolvidos tem impacto proporcionalmente mais relevante. 
Nesse contexto, as menores possibilidades de benefícios domésticos para os países ricos proporcionam com maior freqüência a melhor alternativa possível em comparação às economias menores (Batna-Best Alternative to a Negotiated Agreement), pois os países ricos sempre ofertam o mínimo possível, o que para os países em desenvolvimento já consubstancia promessa de abertura considerável. De maneira inversa, em casos de ameaças envolvendo fechamento de mercado, a mera possibilidade de perder volume exportado é uma tática relativamente menos potente quando usada contra um país desenvolvido do que contra uma pequena economia, visto que o fechamento de mercado para as exportações de um país rico não define, necessariamente, uma queda severa em suas exportações totais. Assim, Steinberg sustenta que países desenvolvidos têm mais poder em um sistema de abertura comercial "por conta da variação virtual do custo de oportunidade relativo de fechamento de mercado". Nesse sentido, ao pedir reciprocidade, os EUA e a CE criam acordos que promovem mudanças/aberturas mais profundas em pequenas economias do que nas suas. Com mercados maiores, os países desenvolvidos sempre estão menos sujeitos aos impactos econômicos de abertura e fechamento comercial (STEINBERG, 2002, p. 347).

Devemos notar que Steinberg salienta esse diferencial em um contexto de reciprocidade. Em uma situação em que não se espera reciprocidade, como era o caso vigente pelo menos até o lançamento da Rodada Uruguai em relação aos países em desenvolvimento ${ }^{41}$, a possibilidade de

\footnotetext{
41 A Declaração Ministerial de setembro de 1986 ainda permite que os países em desenvolvimento não adotem a prática de reciprocidade. "Part B: General Principals Governing Negotiations. [...] (iv) The CONTRACTING PARTIES agree that the principle of differential and more favourable treatment embodied in Part IV and other relevant provisions of the General Agreement and in the Decision of the CONTRACTING PARTIES of 28 November 1979 on Differential and More Favourable Treatment, Reciprocity and Fuller Participation of Developing Countries applies to the negotiations. (v) The developed countries do not expect reciprocity for commitments made by them in trade negotiations to reduce or remove tariffs and other barriers to the trade of developing countries, i.e. the developed countries do not expect the developing countries, in the course of trade negotiations, to make contributions which are inconsistent with their individual development, financial and trade needs" ["Parte B: princí-
}

construção de um Batna por parte dos países ricos é menor, pois as pressões para abertura ou fechamento de mercado não têm grande efeito sobre as economias confiantes na possibilidade de serem "caronas". Diminuir a incidência do tratamento diferenciado deixaria as economias dos países em desenvolvimento mais sujeitas à prática de reciprocidade e, conseqüentemente, ao Batna proposto pelas maiores economias. Não seria inusitado pensar, portanto, que os países desenvolvidos, ao questionarem o tratamento diferenciado, abriam espaço para um incremento ainda maior desse diferencial de poder em relação aos países em desenvolvimento. A reciprocidade absoluta permite às grandes economias um Batna enviesado porque cada país desenvolvido acorda em liberalizar, com base na NMF, dentro de um pacote que privilegia somente aqueles bens produzidos total ou amplamente por sua economia e que sejam passíveis de reciprocidade.

Sustentamos assim que em um ambiente de pura reciprocidade a possibilidade de pactuação assimétrica reflete com mais propriedade o descompasso econômico entre países desenvolvidos e países pobres, pois os side-payments ${ }^{42}$ direcionados aos países menos poderosos têm um efeito doméstico menor para os ricos. Conforme apontamos, isso ocorre por conta da avidez dos mais pobres por concessões, o que os torna sempre mais sujeitos à estrutura jurídica assimétrica produzida pelos países ricos. Nesse sentido, é correto afirmar que são as coalizões entre países

pios gerais governando as negociações. [...] (iv) As PARTES CONTRATANTES concordam que o princípio de tratamento diferenciado e mais favorável incorporado na Parte IV e em outras provisões relevantes do Acordo Geral e na Decisão das PARTES CONTRATANTES de 28 de novembro de 1979 sobre o Tratamento Diferenciado e Mais Favorável, Reciprocidade e Participação Mais Completa dos Países em Desenvolvimento aplica-se às negociações. (v) Os países desenvolvidos não esperam reciprocidade para os compromissos assumidos por eles nas negociações comerciais para reduzir ou remover tarifas e outras barreiras ao comércio dos países em desenvolvimento, i. e., os países desenvolvidos não esperam que os países em desenvolvimento, no curso das negociações comerciais, façam contribuições que são inconsistentes com suas necessidades individuais de desenvolvimento, financeiras e comerciais" - N. E.].

42 Nesse caso, os side-payments significam as aberturas de mercados pontuais a fim de atrair determinado país para o pacote legislativo em voga. 
em desenvolvimento que acabam diminuindo essa necessidade constante por concessões pontuais dos países ricos ${ }^{43}{ }^{44}$. Elas acabam servindo, em última instância, como um anteparo de uma relação direta entre o país rico e o país pobre ${ }^{45}$.

Ainda assim, segundo Steinberg, o mais importante instrumento que os países desenvolvidos utilizam no intuito de ajustar os interesses dos países em desenvolvimento no contexto da "pactuação assimétrica" é a coerção ou a ameaça ${ }^{46}$ 47. Os estados mais fracos e as coalizões podem ser coagidos pelos mais fortes a integrar o

43 Há uma discussão recente que procura entender o papel dessas coalizões nas rodadas multilaterais. Pelo menos três textos destacam-se: Hamilton e Whalley (1989), Narlikar (2003) e Narlikar e Tussie (2004).

44 É importante frisar, nesse sentido, que uma diferença importante entre a Rodada Uruguai e as demais rodadas foi exatamente o aumento das atividades das coalizões, especialmente entre os países em desenvolvimento. Isso não significa que as alianças entre os países em desenvolvimento não fossem ouvidas durante as rodadas Kennedy e Tóquio, mas que na Rodada Uruguai suas atuações foram muito mais ativas e decisivas para o futuro do sistema de comércio (HAMILTON \& WHALLEY, 1989, p. 547).

45 Acreditamos serem várias as motivações da formação de coalizões entre países em desenvolvimento. Podemos citar as mais importantes. A primeira delas tem a ver com o external balancing dos países pobres em relação aos países ricos. É preciso equilibrar as forças dentro do regime, bastante concentradas nas mãos das grandes potências comerciais. O segundo aspecto está relacionado ao aumento do número de votos que uma coalizão promove. A barganha conjunta entre os fracos acaba por favorecê-los no processo de votação. $O$ terceiro fato diz respeito ao incremento dos recursos técnicos das partes por meio da coalizão, que se soma à fragilidade técnica das missões em Genebra, a fim de produzir estudos mais embasados para as negociações. A quarta razão está diretamente ligada ao aumento do tamanho dos mercados. Uma coalizão representa um mercado dilatado se comparada a um país isoladamente. A quinta explicação está ligada à noção de legitimidade. Uma coalizão aumenta a legitimidade das demandas e concessões. A sexta razão relaciona-se aos "caronas". Nas coalizões os membros mais fortes geralmente suportam o peso do freeriding dos menores (NALIKAR, 2003, p. 14-16).

$46 \mathrm{Um}$ dos instrumentos coercitivos mais poderosos no período foi a famosa Seção-301 do 1974 Trade Act. Essa peça legislativa dá ao representante de comércio dos EUA o poder de entender que atos, políticas ou práticas de um governo estrangeiro na área comercial podem ser injustificáveis e trazer restrições ao comércio estadunidense. Constrói-se assim uma estratégia institucional de forçar a abertura externa sem utilização de reciprocidade e sim do "unilateralismo agressivo", termo popularmente cunhado consenso que dá base às medidas inclinadas aos mais poderosos (idem, p. 349).

Quando dirigida a um único Estado, a coerção pode ser considerada uma ameaça. No contexto do lançamento da Rodada Uruguai e pelo menos até o início dos anos 1990, os EUA ameaçaram o Brasil no caso da reserva de informática e fármacos, por exemplo. Odell entende que a ameaça de sansões por parte dos norte-americanos coagiu o Brasil, um dos líderes dos países em desenvolvimento ao lado da Índia, à base de um consenso inclinado aos interesses dos países desenvolvidos e serviu de modelo aos demais que por ventura pensassem em questionar a necessidade de introdução e regulação da propriedade intelectual ${ }^{48}$.

Agora, quando a coerção é dirigida a um grupo de países, como é o caso das coalizões, normalmente toma a forma de uma ameaça de saída ou defecção do regime. Para Steinberg, em alguns casos, a saída envolve a ameaça de mudança da questão a ser tratada para uma organização em que os países mais poderosos tenham maior margem de manobra ${ }^{49}$. Além disso, os estados mais poderosos também ameaçavam sair do regi-

por Jagdish Bhagwati e Hugh Patrick em Aggressive Unilateralism: America's 301 Trade Policy and the World Trading System, de 1990. O paradoxo interessante dessa prática é que se pretende liberalizar o comércio alheio por meio de restrições ao comércio (retaliações) (DAM, 2001, p. 98).

47 Outra forma bastante eficiente de coerção é o "acesso a mercados". A ameaça de fechar o acesso ao mercado para determinado país tem-se mostrado uma arma poderosa daquele que o exerce. Contrariamente, a permissão de acesso a um imenso mercado, como o norte-americano e o europeu, também se tem mostrado um efetivo meio de influência (KEOHANE, 1984, p. 33).

48 O autor argumenta que o governo Reagan, ao decidir tomar medidas gerais para diminuir o enorme déficit comercial do país, utilizou a Seção 301 também com o objetivo de "enquadrar" países desgarrados. Odell identifica que naquele momento de luta contra o déficit, os EUA precisavam de um país em desenvolvimento não asiático como, por exemplo, o Brasil. Essa posição refletia a necessidade dos EUA, no início da Rodada Uruguai, de atacar a liderança dos países em desenvolvimento em propriedade intelectual sob pena de perder legitimidade frente à CE e ao Japão na introdução de serviços, propriedade intelectual e investimentos na nova Rodada (ODELL, 1993, p. 239).

49 O autor cita o caso da propriedade intelectual no início dos anos 1980, quando os EUA não conseguindo maioria 
me no intuito de forçar o encaminhamento das discussões ${ }^{50}$. Havia, portanto, uma argumentação embasada no bandwagoning. Os países menos poderosos seguiriam o mais rico em busca de melhores concessões. As coalizões dos países em desenvolvimento que procuravam bloquear a introdução dos novos temas ficariam isoladas e sem os benefícios das concessões dos mercados mais poderosos. Mas como esse processo de coerção e pactuação assimétrica pode ser mais bem explicado?

De acordo com o autor, a maneira mais fácil de lançar uma Rodada, tendo como base o processo de tomada de decisões de igualdade soberana, reside no estabelecimento do consenso em torno de um mandato negociador bastante vago que inclua as iniciativas e interesses de todos os membros. Os documentos de lançamento de uma Rodada ou os documentos precedentes que preparam o caminho para o lançamento são escritos em uma linguagem ambígua o suficiente para que nenhum país possa bloquear as negociações (idem, p. 350). Identificamos a Declaração Ministerial de 1986 como um bom exemplo disso. O tema de serviços, bastante polêmico à época, acabou sendo introduzido no texto, mas pouco dizia sobre a definição do que era exatamente comércio de serviços e como se dariam as negociações na área. Na Parte II da declaração havia apenas um parágrafo relevante: "Negotiations in this area shall aim to establish a multilateral framework of principles and rules for trade in services, including elaboration of possible disciplines for individual sectors, with a view to expansion of such trade under conditions of transparency and progressive liberalization and as a means of promoting economic growth of all trading partners and the development of developing countries. Such

para regulamentar o tema na World Intellectual Property Organizatinon (WIPO) - por conta do processo de tomada de decisões de maioria simples - mudaram a estratégia e tentaram introduzi-lo no GATT por meio de uma nova Rodada. Outro caso relevante no mesmo período foi a iniciativa norte-americana de transferir a questão de investimentos da OCDE para o GATT, exatamente porque no regime comercial o sistema de tomada de decisões favoreceria sua implementação (STEINBERG, 2002, p. 348-349).

50 Esse procedimento ocorreu quando das ameaças dos EUA de criar o GATT-Plus, caso os países em desenvolvimento continuassem a barrar as discussões de serviços (STEINBERG, 2002, p. 349). framework shall respect the policy objectives of national laws and regulations applying to services and shall take into account the work of relevant international organizations" ${ }^{51}$ (GATT, 1986b, Part II, p. 10).

Uma vez a Rodada lançada, os países começam a elaborar as propostas (tidas pelos demais como interesses tipificados) sobre cada um dos temas em pauta. À medida em que as reuniões são realizadas, tanto dentro do regime como em regimes correlatos (FMI, OCDE, G-7 etc.), os países mais poderosos vão reunindo uma gama considerável de informações sobre as preferências e interesses dos estados mais fracos em diversos temas por meio de declarações, posicionamentos, estudos, working papers e documentos de todos os tipos, providos pelos próprios países em desenvolvimento ou pelos organismos internacionais que os representam, como era o caso da UNCTAD. O tema em pauta serve, portanto, como imã de declarações e posicionamentos de todos os interessados.

Após reunir essa miríade de preferências, as economias mais poderosas têm mais facilidade em construir uma estrutura jurídica assimétrica que encerra a melhor alternativa possível a ser negociada (Batna) (STEINBERG, 2002, p. 350). É importante frisar que, pelo menos aparentemente, os países mais ricos têm pouca informação precisa sobre a constituição dos interesses dos países em desenvolvimento e também dos demais países desenvolvidos. Todo o aparato institucional das potências comerciais ao redor do globo (embaixadas, câmaras de comércio etc.) permite apenas aproximações do que seriam os eventuais interesses dos demais países do regime. É o encaminhamento das Rodadas que faz com que essas informações comecem a circular e os interesses fiquem claros para todos por meio de propostas

\footnotetext{
51 Em inglês, no original: “As negociações nessa área deverão objetivar estabelecer um quadro multilateral de princípios e regras para o comércio de serviços, incluindo a elaboração de possíveis disciplinas para setores individuais, com vistas à expansão desse comércio em condições de transparência e de liberalização progressiva e como uma forma de promover o crescimento econômico de todos os parceiros comerciais e o desenvolvimento dos países em desenvolvimento. Tal quadro deverá respeitar os objetivos políticos das leis e das regulamentações nacionais aplicáveis aos serviços e deverá levar em consideração o trabalho de organizações internacionais relevantes" (N. E.).
} 
concretas levadas à plenária. A partir de então, os países com economias mais diversificadas conseguem construir uma pactuação assimétrica que inclui os interesses de todos, mas que abre possibilidades de ajustes a longo prazo conforme seus interesses ${ }^{52}$

Verificamos no Acordo Multifibras um exemplo desse processo. Discutia-se sobre o período de transição para entrada em vigor do acordo, demanda antiga dos países em desenvolvimento. Os EUA, a CE, o Canadá e a Association of Southeast Asian Nations (Asean) defendiam de maneira conjunta um período de dez anos. Os países do International Textiles and Clothing Bureau (ITCB) ${ }^{53}$ inicialmente apoiavam um período de seis anos. A Índia, por sua vez, apoiava um período de cinco anos, mas ficando isolada, acabou por acordar uma transição de dez anos. Resultado no Dunkel Draft de 1992 ${ }^{54}$ : dez anos de transição para o Acordo Multifibras (STEWART, 1993, p. 17-19). Os países desenvolvidos tiveram mais facilidades em constituir a norma a partir das posições dos países em desenvolvimento colocadas na plenária. Antes de o tema ser discutido era difícil saber com exatidão a proposta dos países do ITCB. Quando a negociação começou, as demandas ficaram mais claras para ambos, favorecendo a construção de uma proposta que envolvesse os desejos parciais de todos, mas tendencialmente inclinada à visão dos importadores de têxteis.

\footnotetext{
52 Winham demonstra processo semelhante ocorrido na Rodada Tóquio. Os países acordaram em negociar barreiras não tarifárias sem efetivamente entenderem muito sobre o tema. A fim de organizar a negociação, as partes adotaram um sistema de notificação durante a fase de prénegociação na qual qualquer país que se sentisse prejudicado por outro incluía uma reclamação no inventário das barreiras não tarifárias. Esse processo gerou uma enorme quantidade de informações a partir das quais foram estruturadas as categorias negociáveis que acabaram se tornando os códigos (codes) da própria Rodada Tóquio (WINHAM, 1986, p. 91-127).

53 O ITCB representava os interesses dos países exportadores de têxteis - todos eles países em desenvolvimento: Bangladesh, Hong Kong, Índia, Indonésia, Jamaica, México, Paquistão, Peru e Turquia.

54 O documento Dunkel Draft de 1992 resume os resultados das negociações até aquele ano. Depois disso houve poucas mudanças nos acordos alcançados, com exceção talvez da área agrícola. O documento levou o nome do então Secretário-Geral da instituição: Arthur Dunkel.
}

Identificamos processo semelhante no tema de subsídios industriais. No subtema Subsidies by Developing Countries ${ }^{55}$, alguns participantes (especialmente os países em desenvolvimento) propuseram a continuação do tratamento diferenciado. Outros (EUA e CE) propuseram maior adoção das obrigações do GATT e do Código de Subsídios por parte dos países em desenvolvimento. Os EUA defendiam o seguinte: "a integração total dos países em desenvolvimento no sistema do GATT, com a adoção de todas as obrigações. Os EUA reconhecem que o período de transição para os países em desenvolvimento pode ser necessário. Os setores competitivos internacionalmente dos países em desenvolvimento devem assumir todas as obrigações do GATT". Já a CE sustentava que: "os países em desenvolvimento devem assumir ao máximo todas as obrigações do GATT. Os setores competitivos internacionalmente dos países em desenvolvimento devem assumir imediatamente todas as obrigações". A Índia, por sua vez, tentava garantir que o "tratamento diferenciado sob o Artigo XIV do Código de Subsídios se mantivesse intacto e que salvaguardas adequadas fossem permitidas contra vantagens indevidas de setores competitivos dos países em desenvolvimento que usassem subsídios" (idem, p. 78-80).

O Dunkel Draft acabou eximindo os países em desenvolvimento listados no Anexo VII por um período de oito anos das proibições do Artigo III, Parágrafo $1^{\circ}$ (proibição de subsídios à exportação e subsídios contingências de exportação). O Anexo VII identificava os least-developed countries e alguns outros países pobres para os quais as provisões do artigo XXVII, $\S 2^{\circ}(\mathrm{b})$ (oito anos para fim dos subsídios) não poderiam ser aplicadas até que estes países alcançassem uma renda per capita de US\$ 1 mil. Todos os demais países em desenvolvimento (Brasil, Argentina, Coréia do Sul, Índia, Egito etc.) deveriam acabar com os subsídios dentro de oito anos. Entretanto, se um país em desenvolvimento alcançasse competitividade na exportação em um setor específico, e se a solicitação de incluir este setor nos oitos anos de prazo fosse negada, os subsídios deveriam ser eliminados em um período de dois anos (idem, p. 74).

Em nossa opinião o tema de subsídios é sintomático porque representava um instrumento cen-

\footnotetext{
55 Em inglês, no original: "Subsídios dos Países em Desenvolvimento" (N. E.).
} 
tral de desenvolvimento econômico dos países da periferia. Por meio de subsídios, agora tidos como ilegais, diversos setores dos países em desenvolvimento alcançaram a competitividade que começava a ameaçar setores correlatos dos países desenvolvidos. Com as propostas dos países em desenvolvimento nas mãos, os países ricos conseguiram criar uma estrutura jurídica que incluía alguns temas importantes para os países pobres como é o caso dos prazos e necessidades de alcançar uma renda per capita mínima - mas que mantinha o núcleo de suas propostas, que era o de aumentar as obrigações de países como a Índia e o Brasil e diminuir a capacidade destes países de subsidiar indústrias que por ventura pudessem competir com suas congêneres no exterior, sem esquecer de enfraquecer o tratamento diferenciado.

É importante lembrar que no caso da Rodada Uruguai muitos países em desenvolvimento sequer apresentavam propostas em temas que não diziam respeito aos seus interesses mais imediatos, normalmente centrados em um pequeno grupo de produtos ou temas. Eram as coalizões dos países em desenvolvimento que acabavam fazendo essas propostas mais amplas (G-10, Grupo de Cairns, Café au Lait etc.), envolvendo os diversos temas em pauta. Ao incluir os interesses de diversos países em desenvolvimento em uma única proposta, os países desenvolvidos tinham dificuldade em qualificar com mais precisão os interesses específicos.

Como comentamos, a pactuação assimétrica para ser efetiva deve abrir a possibilidade de inclusão de interesses pontuais e fundamentais de países-chaves. Deveria incluir, por exemplo, os interesses coreanos nas medidas anti-dumping, os interesses brasileiros em produtos tropicais, os interesses indianos em têxteis etc., sem deixar de lado o grosso das propostas dos países ricos. No entanto, do ponto de vista das necessidades de construção do Batna das potências comerciais, as coalizões apareciam como empecilho, pois dificultavam a cooptação com a inclusão de concessões e abertura pontuais.

Resumindo, os países desenvolvidos, a fim de chamarem os países em desenvolvimento para as discussões, acabam exercendo um poder de barganha de tipo law-based no lançamento da Rodada, respeitando os interesses dos países menos poderosos e incluindo nas declarações iniciais es- ses mesmos interesses, ainda que de maneira vaga. Na medida em que o nível de informações sobre as preferências dos atores aumenta graças aos posicionamentos trazidos à discussão, os países ricos começam a construir uma estrutura jurídica tendenciosa a seus interesses, sem atender os compromissos assumidos em relação aos países em desenvolvimento nas reuniões precedentes ${ }^{56}$.

Caso os países menos poderosos resistam à construção dessa estrutura jurídica, os países ricos utilizam tanto a coerção direta contra um país específico, quanto a ameaça de defecção contra um grupo de países, principalmente contra as coalizões, além dos side-payments direcionados às necessidades pontuais dos mais fracos no intuito de trazer os diversos países em desenvolvimento para dentro da "pactuação assimétrica"57 58.

Nesse contexto, os países em desenvolvimento, em um primeiro momento, tentaram sustentar o tratamento diferenciado alegando que suas dificuldades de balança de pagamentos e necessidades de desenvolvimento ainda existiam e ameaça-

56 O embaixador da Índia em Genebra, Kamalesh Sharitia, já apontava em 1988 a falta de comprometimento dos países ricos com os temas assumidos na Declaração de Punta em 1986 (stand-still e roll-back): "Sharitia said that the central objective of developing a more open, viable and durable multilateral trading system which would liberalize and expand world trade for the benefit of all countries, and particularly third world countries, should not be lost sight of in the conduct and outcome of the negotiations. Progress in the negotiations so far had not been according to expectations. Also, there had been non-implementation of the stand-still and roll-back commitments, with protectionism gaining "new strengthen and adherents"” (THIRD WORLD DISSATISFIED, 1988) ["Sharitia disse que o objetivo central de desenvolver um sistema comercial multilateral mais aberto, viável e durável, que liberalizasse e expandisse o comércio mundial para o benefício de todos os países, e particularmente os países do Terceiro Mundo, não deveria ser perdido de vista na condução e nos resultados das negociações. O progresso das negociações até agora não tem estado de acordo com as expectativas. Além disso, tem havido a não-implementação dos compromissos de stand-still e de roll-back, com o protecionismo ganhando "novos aderentes e força" - N. E.].

57 Uma declaração do embaixador brasileiro Rubens Ricupero nas vésperas para o Mid-term Review de 1988 é indicativa do efeito do mecanismo de coerção bilateral no meio multilateral de negociações: "Brazilian delegate, Amb. Rubens Ricúpero, said heading as it was towards the Midterm Review in December, the negotiations had so far failed to meet third world expectations for 'balanced results' Ricúpero also expressed concern over violations of the 
vam sua plena inserção nas trocas comerciais globais. Quando a situação de defesa do tratamento diferenciado tornou-se insustentável ao longo da Rodada, devido à pressão dos países desenvolvidos tanto por uma harmonização das políticas públicas como em relação aos "caronas", os países em desenvolvimento viram-se obrigados a adotar um posicionamento dentro dos moldes de reciprocidade, mesmo que isso significasse uma pactuação ainda mais assimétrica.

stand-still accord, and cited as a clear example of this the U.S. announcement about its intention to impose unilateral restrictive measures on selected Brazilian exports, purportedly for alleged insufficient protection for patents in pharmaceutical industry in Brazil. The U.S. actions were not only a clear infringement of the stand-still, but a measure for putting pressure on Brazil to change its stance in the negotiating group on TRIPs. 'Such an attitude on the part of the U.S. casts a shadow on the whole atmosphere of negotiations in the round and illustrates the bilateral approach that seems to govern U.S. actions in trade relations and which is a cause of concern for all trading partners" (sem grifos no original) ["O delegado brasileiro, Embaixador Rubens Ricúpero, encabeçando como estava as negociações, disse à Mid-term Review em dezembro, que as negociações até então fracassaram em alcançar as expectativas do Terceiro Mundo por 'resultados balanceados'. Ricúpero também expressou preocupação a respeito das violações do acordo stand-still e citou como um claro exemplo disso o anúncio dos Estados Unidos a respeito de sua intenção de impor medidas restritivas unilaterais em produtos de exportação brasileiros selecionados, aparentemente devido à alegada falta de proteção para as patentes da indústria farmacêutica no Brasil. As ações estadunidenses não são apenas uma clara violação do acordo stand-still, mas uma medida para fazer pressão para o Brasil mudar sua posição no grupo de negociação de TRIPs. 'Tal atitude da parte dos Estados Unidos põe uma sombra em toda a atmosfera de negociações da rodada e ilustra a abordagem bilateral que parece governar as ações dos Estados Unidos nas relações comerciais e que é motivo de preocupação para todos os parceiros comerciais"”- N. E.].

58 Em agosto de 1988 a delegação brasileira em Genebra criticava severamente a atitude bilateral dos EUA no tema de propriedade intelectual. Nos parágrafos que seguem fica clara a intenção norte-americana de mudar o posicionamento brasileiro por meio da coerção: "On July $2^{\text {nd }}, 1988$, the Government of United States of America announced its intention to impose trade restrictions on a number of Brazilian exports items, because alleged damage to the US pharmaceutical industry resulting from Brazilian legislation on patents [...]. This unilateral and discriminatory action constitutes a blatant disrespect of the provisions of the General Agreements. The declared intention of the US Government's action is to force a modification of longstanding Brazilian legislation. This legislation is in full agreement with the appropriate international conventions
É importante frisar nesse sentido que a abertura como resultado da coerção geralmente não é vista como algo passível de reciprocidade pelos demais. A proposta do país rico, provavelmente, não teria a mesma amplitude caso a coerção não fosse efetivamente exercida. Aqueles que foram forçados a liberalizar receberam menos em tro$\mathrm{ca}^{59}$.

Assim, a barganha para o lançamento da Rodada seguiu dentro das normas do regime, as quais intrinsecamente tendem a excluir os diferenciais de poder 60 . Até mesmo as exigências por tratamento diferenciado pelos países em desenvolvi-

regarding intellectual property rights $[\ldots]$. The implementation of the announced measures will cause a serious disruption in the bilateral trade. The mere announcement of this action is already causing serious damage to Brazilian exports interests, thus impairing Brazil's rights under the GATT" (GATT, 1988) ["Em 2 de julho de 1988, o governo dos Estados Unidos anunciou sua intenção de impor restrições comerciais em alguns intens de exportação brasileiros, em virtude da alegação de dano à indústria farmacêutica estadunidense, resultantes da legislação brasileira sobre as patentes [...]. Essa ação unilateral e discriminatória constitui um desrespeito grosseiro das provisões dos Acordos Gerais. A intenção declarada da ação do governo estadunidense é forçar uma alteração da antiquada legislação brasileira. Essa legislação está totalmente de acordo com as apropriadas convenções internacionais relativas aos direitos de propriedade intellectual [...]. A implementação das medidas anunciadas causará uma séria interrupção no comércio bilateral. O mero anúncio dessa ação já causa sérios danos nos interesses de exportação brasileiros, prejudicando, assim, os direitos do Brasil no GATT" - N. E.].

59 A abertura não ocorre unicamente por conta das pressões internacionais. Muitas vezes as autoridades públicas constatam que uma economia bastante fechada precisa de uma certa liberalização a fim de renovar as atividades produtivas, principalmente no que diz respeito à importação de máquinas e equipamentos. Como dizem Tussie e Glover, quando a proteção é muito alta, liberalizar apenas no intuito de barganhar acesso a terceiro mercados é sem sentido (TUSSIE \& GLOVER, 1993, p. 235).

60 Essa afirmação é polêmica. Se as regras são construídas essencialmente pelas grandes potências, elas sempre refletirão o diferencial de poder. Afinal, elas são o resultado jurídico desse diferencial. Nesse sentido, acreditar que as regras excluem as assimetrias de poder ou que são mais eqüitativas parece uma colocação um tanto ingênua. No entanto, os países em desenvolvimento tendem a acreditar que essas regras, sejam elas construídas ou não pelos grandes, são a melhor defesa contra as arbitrariedades unilaterais do poder em um ambiente internacional eventualmente sem regras (lawless). 
mento foram incluídas tanto nos documentos precedentes ao lançamento como nas declarações do início da Rodada; basta ver a importância da "Cláusula de Habilitação" de 1979 para a Declaração Ministerial de $1986^{61}$. Nesse momento de lançamento, vemos que as coalizões entre países em desenvolvimento possuíam alta capacidade de negociação: mais em função desse tipo de pactuação institucional, que procura atrair os países resistentes, do que pela falta de coesão entre os ricos ou ainda por conta de um contexto global favorável (embate Norte-Sul na Guerra Fria). Aparentemente, preferimos entender esse poder relativamente maior dos países pobres no início da Rodada Uruguai como resultante do fato de os países desenvolvidos ainda não usufruírem plenamente das informações sobre as preferências dos mais fracos.

É importante frisar, contudo, que esse processo de pactuação assimétrica implica uma noção genérica sobre os resultados dos temas tratados ao longo da Rodada. Em alguns casos, os países em desenvolvimento conseguiram manter uma posição mais restritiva, como no tema de serviços, e os resultados não foram tão inclinados aos países mais ricos ${ }^{62}$. Contudo, naqueles temas em que o interesse dos países em desenvolvimento era fundamental, como o caso agrícola, de têxteis e até mesmo a propriedade intelectual, os resultados do Dunkel Draft demonstraram como os países desenvolvidos souberam montar uma estrutura jurídica que melhor encerrasse seus desejos ${ }^{64}$.

61 Cf. nota 41.

62 Sobre a pouca capacidade de operação do General Agreement on Trade in Services (GATS) favor verificar o interessante texto de Sauvë (1995).

63 A Índia manteve uma posição bastante restritiva em serviços durante toda a Rodada. Em grande medida esse posicionamento decorria da estatização de vários serviços contemplados pelo GATS (bancos, seguradoras, companhias aéreas, hotéis e restaurantes) (DESAI, 1989, p. 106).

64 A agricultura, a despeito da enorme pressão do Grupo de Cairns, acabou em um acordo bilateral entre os EUA e a CE que instituiu a "Cláusula da Paz", postergando decisões importantes no tema. Por pressão dos países ricos, a área de têxteis seria incluída definitivamente no regime somente após um prazo de dez anos. Não era claro em 1994 que os comprometimentos em propriedade intelectual e outras regulações seriam traduzidos em acesso a mercados para os países em desenvolvimento.
Enfim, os países em desenvolvimento foram paulatinamente adotando os princípios e temas propostos pelos países ricos. Ao final da Rodada em 1994 o tratamento diferenciado já havia perdido muito de sua operacionalidade e os novos temas foram definitivamente incluídos, principalmente os de propriedade intelectual e serviços. Claro que as mudanças de posicionamento dos países em desenvolvimento, ao longo da rodada, não foram uníssonas. Os diversos países foram, aos poucos, alterando a estratégia no GATT. Em nosso entendimento o que acabou balizando a atuação mais ou menos coordenada de alguns e menos organizada de outros foram as coalizões (G-10, Café au Lait, Grupo de Cairns, Food Importers, Friends of Services e G-48). A atuação dessas coalizões fez com que alguns países demorassem mais para adotar um posicionamento com base na reciprocidade e, conseqüentemente, liberalizante. Outros que não enxergavam as coalizões como estratégia interessante adotaram a reciprocidade de maneira mais decidida desde o início das tratativas, como foram os casos do México e da Coréia do Sul. Para entender esse processo é importante dividir a Rodada em algumas fases.

\section{AS MUDANÇAS DE POSIÇÃO DOS PAÍ- SES EM DESENVOLVIMENTO NA RODA- DAURUGUAI}

Como afirmamos ao longo do artigo, os países em desenvolvimento, cientes de sua situação peculiar, demandavam tratamento diferenciado e, devido a um ambiente internacional que os favorecia, conseguiram introduzir no regime comercial um grupo de regras que asseguravam concessões (Parte IV e Cláusula de Habilitação). Os países desenvolvidos, por sua vez, sempre adotaram um posicionamento recíproco e, por isso, mais bilateralista nas negociações.

Para nós é claro que o lançamento da Rodada Uruguai entre 1982 e 1986 é sintomático tanto para o posicionamento dos países ricos como para o dos países pobres. Pelo lado dos desenvolvidos, o período compreendido entre a Reunião Ministerial de 1982 e o Mid-Term Review de $1988^{65}$ é caracterizado pela proposição (novos temas) e pelo questionamento dos privilégios (tra-

\footnotetext{
65 Revisão de Meio-termo: uma reunião que tinha como objetivo a compilação dos resultados alcançados ate o momento a fim de direcionar os esforços para a próxima Reunião Ministerial.
} 
tamento diferenciado). Inversamente, pelo lado dos países em desenvolvimento, o mesmo período é caracterizado por um questionamento ${ }^{66}$ (novos temas) e, fundamentalmente, pela manutenção do status quo adquirido ao longo das duas últimas décadas (tratamento diferenciado).

Procuramos frisar que entre o Mid-Term Review de 1988 em Montreal e a Reunião Ministerial de Bruxelas em 1990 as posições começaram a sincronizar. De Bruxelas a Marraqueche em 1994 o embate maior era entre a CE e os EUA; desenvolvidos e em desenvolvimento já haviam diminuído a intensidade das querelas. Em 1988 os países em desenvolvimento deixaram de questionar os novos temas e começaram a negociá-los por meio de propostas mais específicas. Os países desenvolvidos, por sua vez, começaram a adotar critérios mais impositivos no intuito de constituir um resultado mais condizente com seus interesses. A partir de 1990, os países em desenvolvimento já não mais conseguiam sustentar a manutenção de um tratamento diferenciado tão amplo como o das décadas anteriores e iniciaram um posicionamento recíproco, tendo como base a abertura unilateral e sem contrapartidas. Como vimos, as práticas de coerção e ameaça tiveram impacto decisivo nessas mudanças.

TABELA 1 - POSICIONAMENTO DOS PAÍSES EM DESENVOLVIMENTO

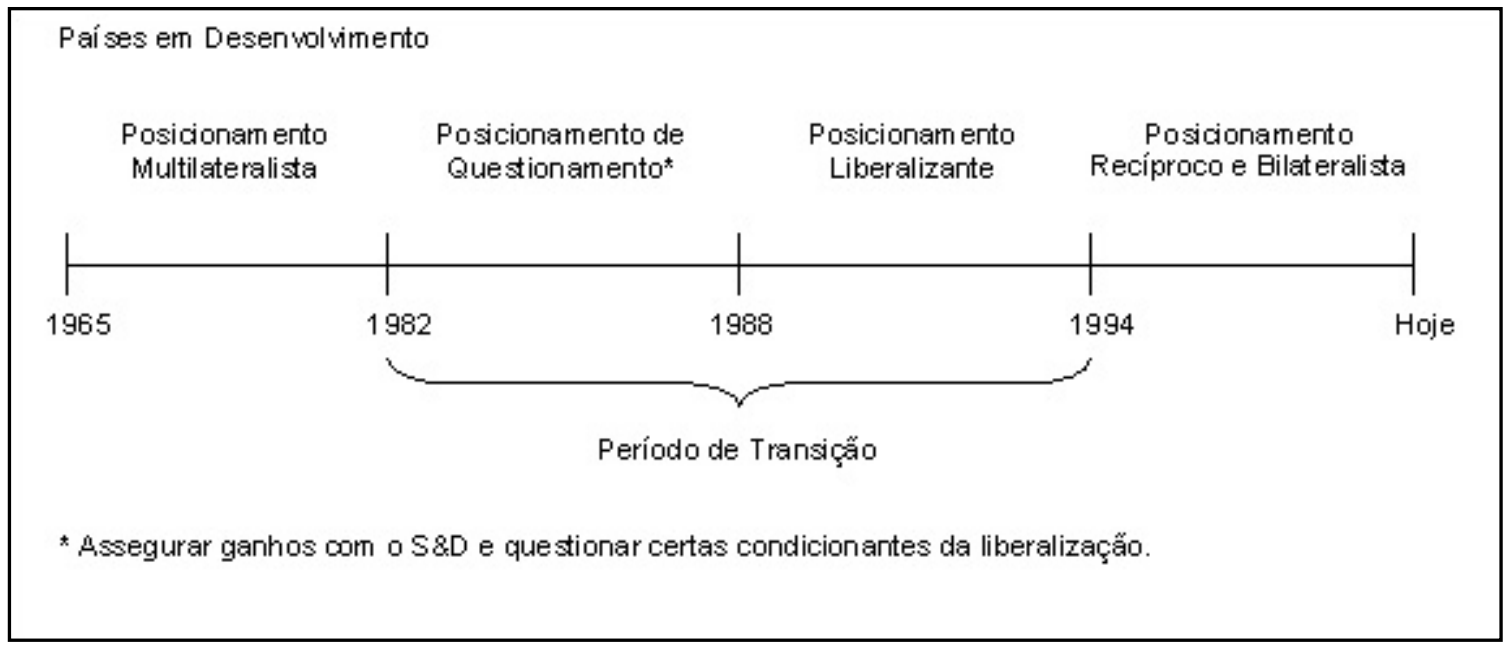

FONTE: $o$ autor.

TABELA 2 - POSICIONAMENTO DOS PAÍSES DESENVOLVIDOS

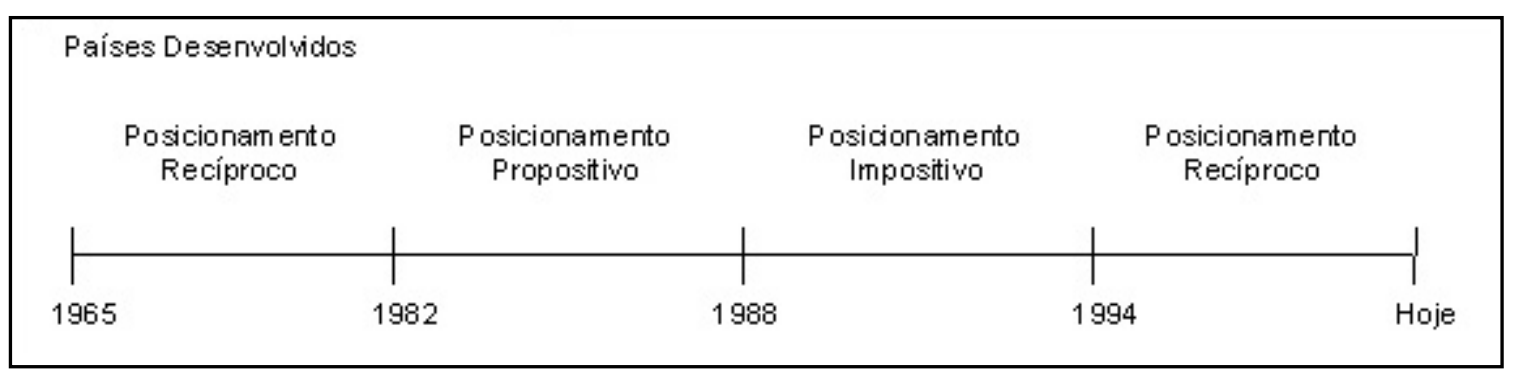

FONTE: 0 autor.

66 A literatura especializada geralmente caracteriza a atitu-
de dos países em desenvolvimento nessa fase como
blocking position. Esse termo parece ser um pouco exage-
rado, pois as declarações do período refletiam mais uma postura de questionamento da validade dos novos temas dentro do GATT do que exatamente uma atitude de bloqueio das negociações. Por isso, a postura é caracterizada como de questionamento nesse texto. 
É importante frisar que não existe um momento de inflexão no posicionamento dos países em desenvolvimento. Ao contrário, a reestruturação da estratégia é caracterizada por um longo processo que tem a ver tanto com o ambiente de pressão dos países ricos como de eclosão das coalizões. Podemos afirmar apenas que as mudanças ocorreram entre o nascimento do G-1067 em 1982 e a conclusão do Dunkel Draft em 1992, período, obviamente, muito extenso.

No entanto, acreditamos que as reuniões de Montreal e Bruxelas podem simbolizar um marco em pelo menos um aspecto: a disposição dos países em desenvolvimento de negociarem políticas públicas, ou seja, de não mais rejeitarem os novos temas, mas finalmente aceitá-los como parte integrante da negociação e de seu possível sucesso.

De acordo com Croome, na reunião de 1988 em Montreal os ânimos estavam exaltados. Quatro questões trancavam a pauta de negociações: agricultura, têxteis salvaguardas e TRIPs. O ponto de maior fricção era a área agrícola com os EUA e a CE mantendo posições opostas e irreconciliáveis. Por um lado, os EUA desejavam liberalização total em dez anos e, por outro, a CE mantinha a posição de ceder apenas gradualmente no apoio interno à agricultura. $\mathrm{O}$ impasse agrícola levou a reunião a um fim abrupto (CROOME, 1995, p. 172-173).

Ao final das tratativas os resultados eram confusos. Houve progresso substantivo e impasses ferrenhos. Segundo Preeg, o maior passo a frente foi dado em serviços e propriedade intelectual. O mínimo havia sido alcançado pelos países desenvolvidos. Os dois temas foram incorporados definitivamente na estrutura jurídica da negociação e, em troca, os países em desenvolvimento obtiveram um comprometimento dos países ricos na abertura do Acordo Multifibras (PREEG, 1995, p. 92).

Essa barganha demonstrou que pela primeira vez os países em desenvolvimento estavam prontos a negociar padrões de comércio em um tema novo: a propriedade intelectual. Preeg sustenta que a Índia e outros "linhas-duras"68 finalmente acei-

67 O G-10 englobava dez países em desenvolvimento, liderados por Argentina, Brasil, Índia, Egito e Iugoslávia, que se opunham à proposta norte-americana de uma nova rodada.

68 País linha-dura é uma caracterização dos países que se opunham à introdução dos novos temas. Embora criticável, taram a importância de uma bem-sucedida conclusão das negociações multilaterais de TRIPs daquele momento em diante. As negociações iriam incluir a aplicabilidade dos princípios do GATT sobre o tema, a adequação de padrões e princípios, a introdução da propriedade intelectual nas legislações nacionais e a modalidade do tema para o órgão de soluções de controvérsias (PREEG, 1995, p. 90-91). Entretanto, Croome argumenta que a Índia e o Brasil insistiram em negociações que reconhecessem interesses públicos como saúde, desenvolvimento e acessibilidade a tecnologias (CROOME, 1995, p. 173-174).

As colocações de Preeg e Croome nos indicam que o processo de mudança tem seus primeiros sinais na Reunião de Montreal. O fato de países como a Índia e o Brasil cederem nas negociações de TRIPs, ainda que buscassem certas concessões como a defesa da saúde pública, reflete que a estratégia de questionamento estava fadada ao insucesso. As ameaças de uso da Seção-301 por parte dos EUA contra o Brasil e outros países em desenvolvimento já haviam surtido efeito no final dos anos 1980. A mera possibilidade de perder mercados importadores consideráveis afetou países que sofriam com problemas na balança de pagamentos, principalmente aqueles com dívida externa elevada ${ }^{69} 70$. A sustentabilidade das regras de tratamento diferenciado não poderia mais ser mantida em sua plenitude, uma vez que a adoção de acordos em temas que represen-

a alcunha é recorrente na literatura especializada.

69 A ligação entre comércio e finanças já havia sido discutida e introduzida na Declaração Ministerial de 1986. Desde então os problemas de balança de pagamentos são discutidos nas reuniões, mas os países desenvolvidos não aceitavam disponibilizar eventuais concessões comerciais, tendo em vista problemas financeiros, embora exercessem pressão em relação aos países devedores quando precisavam aprovar tema de interesse no GATT.

70 Há certa contradição entre a regra de reciprocidade do GATT e a pressão das agências financeiras internacionais (FMI e Banco Mundial) por aberturas unilaterais. A abertura unilateral promovida por um país em desenvolvimento, seja por conta de uma crise financeira e a conseqüente pressão do FMI por liberalização econômica, seja pela decisão autônoma de que a liberalização é a melhor estratégia frente a um mundo globalizado, tende a não ser vista pelos demais países do regime como uma concessão. O país em questão abriu sua economia porque assim quis ou foi coagido a fazê-lo. Não há porque barganhar nada em troca. Logo, não há reciprocidade (ABREU, 1993, p. 148). 
tavam a harmonização de políticas públicas impossibilitava concessões e forçava a aproximação de deveres e direitos.

Finalmente, o Dunkel Draft de 1992 sugeria que o tratamento diferenciado fosse totalmente revisto. $\mathrm{O}$ documento meramente autorizava os países em desenvolvimento a longos períodos de ajustes ou assistência técnica para cumprir as mesmas obrigações dos países ricos (TUSSIE, 1993, p. 79). Ao contrário do que geralmente se afirma, portanto, acreditamos que os países em desenvolvimento caminharam, ao longo da Rodada Uruguai, do multilateralismo para um bilateralismo com ares de multilateralismo e, sem ter os mesmos atributos econômicos, adotaram a estratégia dos países ricos: a reciprocidade.

\section{CONSIDERAÇÕES FINAIS}

Tendo em vista esse cenário, retomamos a pergunta colocada anteriormente. Os países em desenvolvimento adotaram a reciprocidade (liberalização) por que a entendiam como a melhor estratégia? Ou caminharam para o comportamento recíproco por que o processo de coerção dos países desenvolvimento não deixou outras alternativas?

A hipótese que levantamos no início do texto inclina-se para o segundo aspecto. O leque de possibilidades estratégicas restringiu-se à adoção da reciprocidade e à aceitação dos novos temas. Nesse sentido, o tratamento diferenciado não mais correspondia em 1994 à sua característica inicial, construída desde 1965. A reciprocidade tornouse a prática usual também dos pequenos, levando-os a tipo de negociação sem o recurso de qualquer anteparo jurídico que assegurasse suas condições econômicas particulares.

$\mathrm{O}$ que procuramos enfatizar ao longo desse artigo é o fato de que as pressões externas (ameaça ou retaliação), e um mecanismo de tomada de decisões tendencioso aos países ricos, coagiram os países em desenvolvimento a uma única saída: liberalizar, ainda que isso significasse diversos e destoantes projetos de abertura. Um exemplo disso seria o fato de que, uma vez aceita a proposta das potências comerciais, os países em desenvolvimento criaram novas estratégias, agora mais ligadas à tentativa de aplacar o caráter vinculante das regras, principalmente em novos temas. Acatam-se os novos princípios, mas não se facilita a operação mais concreta das regras.

Com efeito, o fim do tratamento diferenciado e a aceitação dos novos temas significavam liberalizar a economia, porém esse processo era por demais amplo, vago e ambíguo, permitindo a adoção de estratégias divergentes entre os países em desenvolvimento: algumas mais francas no sentido da diminuição da participação do Estado na economia (Coréia do Sul e México) e outras ainda um pouco resistentes (Brasil e Índia). Até que ponto essas estratégias têm trazido resultados satisfatórios ainda é uma página aberta.

Feliciano de Sá Guimarães (marirai@usp.br) é Mestre em Relações Internacionais pela Universidade Estadual de Campinas (Unicamp) (Programa San Tiago Dantas) e Professor de Cooperação Internacional e Negociações Internacionais nas Faculdades Belas Artes de São Paulo.

\section{REFERÊNCIAS BIBLIOGRÁFICAS}

ABREU, M. \& FRITSCH, W. 1987. Brazil, Latin America and the Caribbean. In : WHALLEY, J. (ed.). Dealing with the North : Developing Countries and the Global Trading System. London: CSIER.

ABREU, M. 1993. Trade Policies and Barganing in a Heavily Indebted Economy : Brazil. In : TUSSIE, D. \& GLOVER, D. (eds.). The Developing Coutries in World Trade: Policies and Barganing Strategies. London : L. Rienner.
BALDWIN, R. 1984. U.S. Trade Policy since World War II. In : KRUEGER, A. \& BALDWIN, R. E. (eds.). The Structure and Evolution of Recent U.S. Trade Policy. Chicago : University of Chicago.

BARON, D. \& FAREJOHN, J. 1989. Bargaining in Legislatures. American Political Science Review, Washington, D. C., v. 83, n.4, Dec.

BUZAN, B. 1981. Negotiating by Consensus : Developments in Technique at U.N. : Conference on the Law of the Sea. American 
Journal of Internacional Law, v. 75, n. 2, p. 324-348, Apr.

CROOME, J. 1995. Reshaping the World Trading System : a History of the Uruguay Round. Geneva : World Trade Organization.

DAM, K. 1970. The GATT : Law and International Economic Organization. Chicago : The Chicago University.

2001. The Rules of the Global Game: a New Look at U.S. International Economic Policymaking. Chicago : The Chicago University.

DESAI, A. 1989. The Politics of India's Trade Policy. In : NAU, H. (ed.). Domestic Trade Politics and the Uruguay Round. Nova Iorque : Columbia University.

DIELBOLD JR., W. 1967. New Horizons in Foreign Trade. Foreign Affairs, Palm Coast, p. 299, Jan.

EVANS, J. 1971. The Kennedy Round and American Trade Policy : the Twilight of the GATT? Cambridge : Harvard University.

FINLAYSON, J. \& ZACHER, M. 1983 The GATT and the Regulation of Trade Barriers : Regime Dynamics and function. In : KRASNER, S. (ed.). International Regimes. Ithaca : Cornell University.

GOLDSTEIN, J. 1998. Creating GATT Rules : Politics, Institutions, and American Policy. In : HOWSE, R. (ed.). The World Trading System : Critical Perspectives on the World Economy. London : Routledge.

GOLT, S. 1977. Developing Countries in the GATT System. London : Trade Policy Research Center.

. 1979. The GATT Negotiations (19731979) : The Closing Stage. Washington, D.C. : British-North American Committee.

GRIECO, J. 1990. Cooperation among Nations : Europe, America and Non-Tariff Barriers to Trade. Ithaca : Cornell University.

HAMilTON, C. \& WHALLEY, J. 1989. Coalitions in the Uruguay Round. Weltwirtschaftliches Archiv: Review of World Economics, Journal of the Kiel Institute of World Economics.
HUDEC, R. 1998. The Role of the GATT Secretariat in the Evolution of the WTO Dispute Settlement Procedure. In : BHAGWATI, J. \& HISCH M. (eds.). The Uruguay Round and Beyond. Ann Arbor: The University of Michigan.

KRASNER, S. 1983. Structural Causes and Regime Consequences : Regimes as Intervening Variables. In : . (ed.). International Regimes. Ithaca : Cornell University.

KEOHANE, R. 1986. Reciprocity in International Relations. International Organization, v. 40, p. 1-27.

1984. After Hegemony : Cooperation and Discord in the World Political Economy. Princeton : Princeton University.

KIHWAN, K. \& SOO, C. H. 1989. Korea's Domestic Trade Politics and the Uruguay Round. In : NAU, H. (ed.). Domestic Trade Politics and the Uruguay Round. New York : Columbia University.

LIMA, M. R. S. \& HIRST, M. 1994. O Brasil e os EUA : dilemas e desafios de uma relação complexa. In : FONSECA JR., G. \& CASTRO, S. H. (orgs.). Temas de Política Externa Brasileira II. V. 2. Brasília : Fundação Alexandre de Gusmão.

LIPSON, C. 1983. The Transformation of Trade : Sources and Effects of Regime Change. In : KRASNER, S. (ed.). International Regimes. Ithaca : Cornell University.

MACIEL, G. 1986. O Brasil e o GATT. Contexto Internacional, Rio de Janeiro, ano 2, n. 3, p. 84-85.

MACLAREN, R. 1980. The Geo-Political Changes during the 1980's and their Influence on the GATT. In : BHAGWATI, J. \& HIRSCH, M. (eds.). The Uruguay and Beyond : Essays in Honor of Arthur Dunkel. Ann Arbor : The University of Michigan.

MELLO, F. C. 1992. O Brasil e o GATT : análise da posição brasileira nas negociações comerciais multilaterais. Rio de Janeiro. Dissertação (Mestrado em Relações Internacionais). Pontifícia Universidade Católica do Rio de Janeiro. 
NARLIKAR, A. 2003. International Trade and Developing Countries : Bargaining Coalitions in the GATT \& WTO. London : Routledge.

NARLIKAR, A. \& TUSSIE, D. 2004. Bargaining Together in Cancun: Developing Countries and Their Evolving Coalitions. mimeo, Exter, UK e Buenos Aires.

ODELL, J. 1993. International Threats and Internal Politics : Brazil, the EC and the USA, 1985-1987. In : PUTNAM, R. EVANS, P. \& JACOBSON, H. (eds.). Double-Edge Diplomacy. Berkley : University of California.

OXLEY, A. 1990. The Challenge of Free Trade. London : Harvester Wheatsheaf.

PREEG, E. 1970. Traders and Diplomats : An Analysis of the Kennedy Round of Negotiations under the GATT. Washington, D.C. : Brooks.

. 1995. Traders in a Brave New World: The Uruguay Round and the Future of the International Trading System. Chicago : Chicago University.

RICUPERO, R. 1998. Integration of Developing Countries into the Multilateral Trading System. In : BHAGWATI, J. \& HIRSCH, M. (eds.). The Uruguay and Beyond: Essays in Honor of Arthur Dunkel. Ann Arbor : University of Michigan.

RUBIO, L.; RODRIGUES, C. \& BLUM, R. 1989. Mexico's Trade Policy and the Uruguay Round. In : NAU, H. (ed.). Domestic Trade Policy and the Uruguay Round. New York : Columbia University.

STEINBERG, R. 2002. In the Shadow of Law or Power? Consensus-Based Bargaining and Outcomes in the GATT/WTO. International
Organization, Cambridge, Mass., v. 56, n. 2, p. 357-358.

SAUVË, P. 1995. Assessing the GATS - HalfFull or Half-Empty? Journal of World Trade, London, v. 29, n. 4.

STEWART, T. 1993. The GATT Uruguay Round: A Negotiating History. Boston : Kluwer.

TUSSIE, D. 1993. The Uruguay Round and the Trading System in the Balance : Dilemmas for Developing Countries. In : AGOSTIN, M. \& TUSSIE D. (eds.). Trade and Growth : New Dilemmas in Trade Policy. London : St. Martin.

TUSSIE, D. \& GLOVER, D. 1993. Implications for Bargaining. In:__ _. (eds.). The Developing Countries in World Trade : Policies and Bargaining Strategies. London : L. Rienner.

TUSSIE, D. \& LENGYEL, M. 2003. Developing Countries : Turning Participation into Influence. In : HOEKMAN, B. (ed.). Development, Trade and the WTO : A Handbook. Washington, D. C. : The World Bank Group.

VELASCO E CRUZ, S. 2005. O sistema multilateral do comércio e os países da periferia : uma análise política. Digit.

WINHAM, G. 1986. International Trade and Tokyo Round Negotiation. Princeton : Princeton University.

WHALLEY, J. \& HAMILTON, C. 1987. A View from the Developed World. In : WHALLEY, J. (ed.). Dealing with the North : Developing Countries and the Global Trading System. London : CSIER.

ZEILER, T. 1991. American Trade Power in the 1960s. New York : Columbia University.

\section{OUTRAS FONTES}

GATT. 1947. The General Agreement on Tariffs and Trade (GATT 1947). Disponível em : http:/ /docsonline.wto.org/. Acesso em : 15.dez.2006.

1977. Statement by the Representative of Brazil, H.E. Ambassador George A. Maciel, on February 22. MTN/FR/W/1. Disponível em : http://www.wto.org/gatt_docs/ English/SULPDF/92010123.pdf. Acesso em : 15.dez.2006.
1979. Differential and More Favourable Treatment, Reciprocity and Fuller Participation of Developing Countries. Decision of 28 November 1979 (so-called "Enabling Clause"). Disponível em : http:// docsonline.wto.org/. Acesso em : 15.dez.2006.

1986a. Draft Ministerial Declaration. Preparatory Committee (86)w/41, de 23.June. Disponível em : http://www.wto.org/gatt_docs/ 
English/SULPDF/91210168.pdf. Acesso em : 15.dez.2006.

1986b. Ministerial Declaration on the Uruguay Round (Punta del Este, 20 September 1986). Disponível em : http://www.wto.org/ gatt_docs/English/SULPDF/91240152.pdf. Acesso em : 15.dez.2006.

. 1986c. News of the Uruguay Round of Multilateral Trade Negotiations. Geneva, Oct., at.1.

1988. United States - Import Restrictions on Certain Products from Brazil. Request by Brazil. L/6386, de 24.ago. Disponível em : http://www.wto.org/gatt_docs/English/ SULPDF/91370059.pdf. Acesso em : 15.dez.2006.
1994. General Agreement on Tariffs and Trade (GATT 1994). Disponível em : http:// docsonline.wto.org/. Acesso em : 15.dez.2006.

Third World Dissatisfied with Uruguay Round Processes. 1988. SUNS Online, Geneva, 29.Sept. Disponível em : http://www.chasque.net/ frontpage/suns/trade/process/during/uruguay/ tnc/09290088.htm. Acesso em : 15.dez.2006.

US Moves on Trade in Services, Investment Issues Meet with Increasing Third World Resistance. 1982. SUNS Online, Geneva, 17.June. Disponível em : http://www.chasque.net/frontpage/ suns/trade/process/during/82/06170082.htm. Acesso em : 15.dez.2006. 